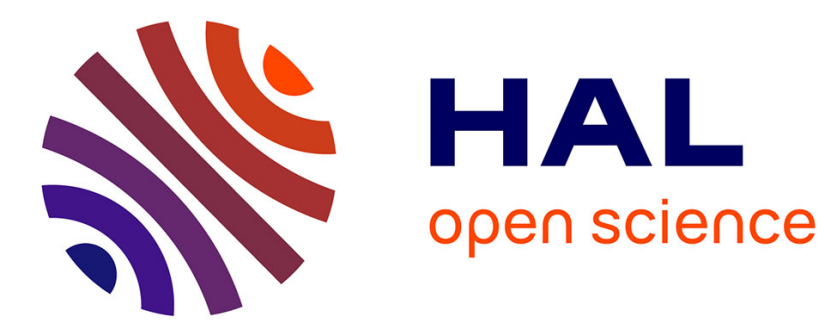

\title{
In situ 'Trans-metal Trapping': an Efficient Way to Extend the Scope of Aromatic Deprotometalation
}

Nahida Brikci-Nigassa, Ghenia Bentabed-Ababsa, Florence Mongin, William Erb

\section{- To cite this version:}

Nahida Brikci-Nigassa, Ghenia Bentabed-Ababsa, Florence Mongin, William Erb. In situ 'Transmetal Trapping': an Efficient Way to Extend the Scope of Aromatic Deprotometalation. Synthesis: Journal of Synthetic Organic Chemistry, 2018, 50 (18), pp.3615-3633. 10.1055/s-0036-1591953 . hal01902075

HAL Id: hal-01902075

https://hal-univ-rennes1.archives-ouvertes.fr/hal-01902075

Submitted on 23 Oct 2018

HAL is a multi-disciplinary open access archive for the deposit and dissemination of scientific research documents, whether they are published or not. The documents may come from teaching and research institutions in France or abroad, or from public or private research centers.
L'archive ouverte pluridisciplinaire HAL, est destinée au dépôt et à la diffusion de documents scientifiques de niveau recherche, publiés ou non, émanant des établissements d'enseignement et de recherche français ou étrangers, des laboratoires publics ou privés. 


\title{
In situ 'Trans-metal Trapping': an Efficient Way to Extend the Scope of Aromatic Deprotometalation
}

\author{
Nahida Mokhtari Brikci-Nigassa ${ }^{a, b}$ \\ Ghenia Bentabed-Ababsa ${ }^{a}$ \\ William Erb*b \\ Florence Mongin*b \\ a Laboratoire de Synthèse Organique Appliquée, Faculté des \\ Sciences Exactes et Appliquées, Université d'Oran 1 Ahmed \\ Ben Bella, BP 1524 El M'Naouer, 31000 Oran, Algeria

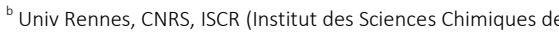 \\ Rennes) - UMR 6226, F-35000 Rennes, France \\ william.erb@univ-rennes1.fr \\ florence.mongin@univ-rennes1.fr

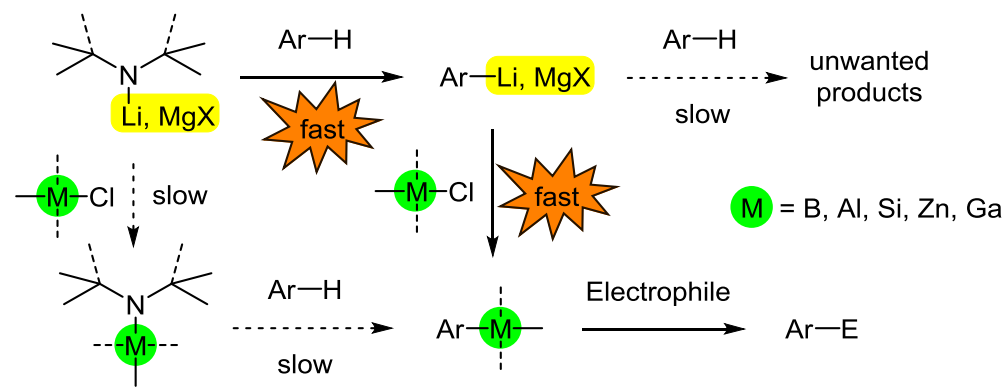 \\ Click here to insert a dedication.
}

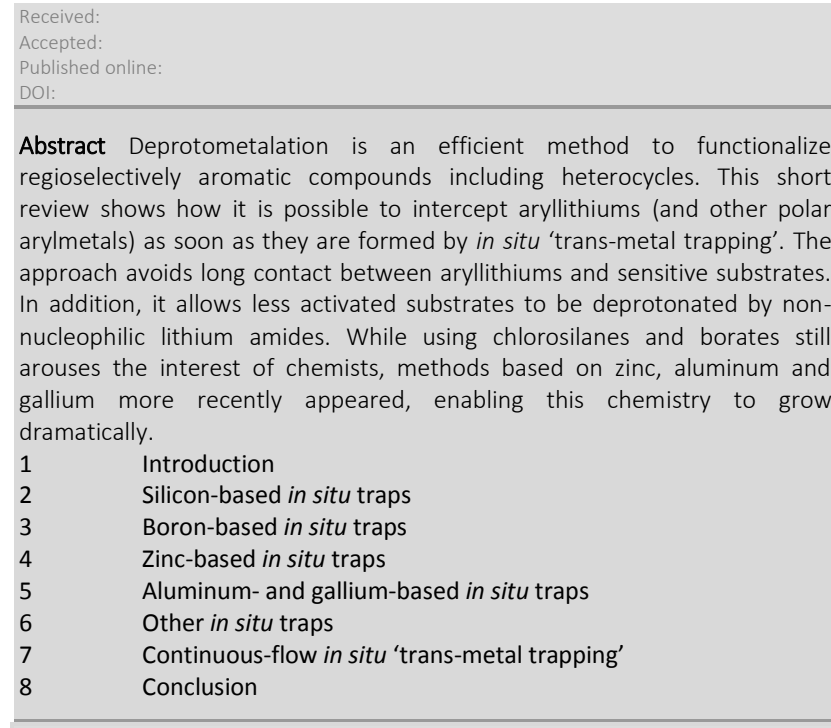

Key words transmetalation; in situ trap; deprotometalation; aromatic compounds; lithium amides; silicon; boron; zinc

\section{Introduction}

Deprotometalation followed by electrophilic trapping is a powerful method to functionalize aromatic compounds. ${ }^{1}$ Regioselectively is in general ensured through the use of directing groups that (i) stabilize the generated arylmetals by intramolecular coordination and/or electron-withdrawing effect (under thermodynamic control), or (ii) favor the reaction by coordination to the base and/or hydrogen acidification (under kinetic control).

The limits of deprotolithiation and -magnesation result from the high ionic character of the carbon-metal bond. Consequently, the aromatic substrates can be weakly compatible with the generated arylmetals, e.g. in case of sensitive directing groups or heterocycles prone to nucleophilic attacks. The arylmetals can also be unstable, e.g. in the presence of adjacent halogens to release metal halides. In addition, from activated or sensitive aromatics including heterocycles, classical deprotolithiation followed (after a contact time) by electrophilic quenching in general affords the most stable lithio compounds; therefore, there is a need for tools to access other regioselectivities resulting from the kinetic ones.

Besides using low temperatures or monometallic bases containing softer metals, ${ }^{2}$ more recent studies have shown that lithium -ate bases (e.g. zincates) and Turbo bases can be more efficiently employed to achieve chemoselective deprotonative metalations. ${ }^{3}$ Nevertheless, these bimetallic deprotonating agents can imply either the presence of additives that may be unwanted for the following reactions, or the generation of arylmetal species unsuitable for subsequent trappings. They can also fail in affording the required regioisomers.

In situ 'trans-metal trapping' is a way to address these issues by intercepting the arylmetals with an electrophilic trap as soon as they are formed. In addition, by pushing the reaction to completion, it is an efficient alternative to external quench for reversible reactions not benefiting from the required difference of four $\mathrm{p} K_{\mathrm{a}}$ units between the base and the substrate. ${ }^{4}$

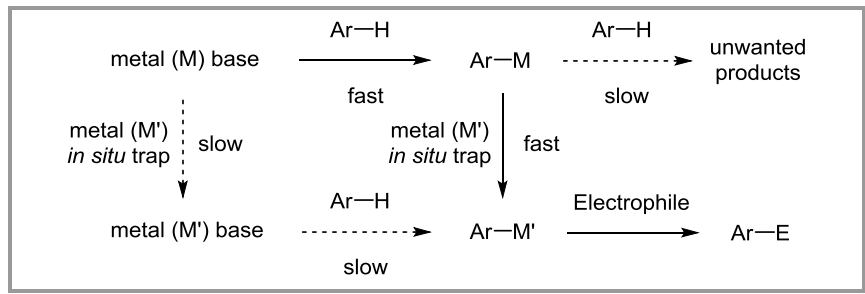

Scheme 1 Principle of in situ trapping metalation (dashed arrows indicate unwanted pathways)

The method applies if the base (metal M) rather reacts with the substrate $(\mathrm{Ar}-\mathrm{H})$ than with the in situ trap (metal or semi-metal 
$\left.\mathrm{M}^{\prime}\right)$, and if the arylmetal (Ar-M) is quenched by the in situ trap rather than by unwanted reactions (Scheme 1). ${ }^{5}$ In practice, sterically encumbered bases such as lithium diisopropylamide (LiDA) or lithium 2,2,6,6-tetramethylpiperidide (LiTMP) can in general be used. ${ }^{6}$

As regards the electrophilic traps, whereas chlorosilanes and borates have been employed since the eighties, more recent studies have identified zinc, aluminum and gallium species as appropriate to this purpose. ${ }^{7}$ In this Short Review, our goal is to focus on examples using this method and thus display its applications to the functionalization of aromatics including heterocycles.

\section{Silicon-based in situ traps}

That chlorotrimethylsilane could accelerate deprotometalation was already noticed in 1982 by reacting 2-bromopyridine with LiDA in tetrahydrofuran (THF) at low temperatures. ${ }^{8}$ Although LiDA is not a conventional base for benzene proton abstraction, it turns out to be one in the presence of such a trap capable of intercepting the aryllithium as soon as it is formed.

The first complete study on in situ trapping (here, using chlorotrimethylsilane) as a way to allow sensitive aromatic compounds to be deprotolithiated was reported in $1983 .{ }^{9}$ Without in situ trap, benzonitrile cannot be lithiated by LiDA at temperatures below $-90^{\circ} \mathrm{C}$ whereas LiTMP gave average yields at $\quad-78 \quad{ }^{\circ} \mathrm{C} \quad(2$-(trimethylsilyl)benzonitrile: $53 \%$; 2 iodobenzonitrile: $35 \%$; 3 -phenylphthalide: $40 \%$ after warming with diluted aqueous $\mathrm{HCl}$ ) and degradation at higher temperatures. ${ }^{9}$ As regards alkyl benzoates, deprotolithiation using LiTMP takes place at $-78^{\circ} \mathrm{C}$, but leads to self-condensation products in the absence of in situ trap. ${ }^{10}$ Krizan and Martin relied on the LiTMP-chlorotrimethylsilane tandem to functionalize benzonitrile, benzene esters and pivalophenone (Table 1). ${ }^{9}$

Table 1 Functionalization of benzonitrile, isopropyl and ethyl benzoate, and pivalophenone using the LiTMP-chlorotrimethylsilane pair

\begin{tabular}{|c|c|c|}
\hline & $\begin{array}{l}\mathrm{LiTMP}_{\text {(x equiv) }} \\
\mathrm{CISiMe}_{3} \text { (y equiv) }\end{array}$ & \\
\hline & \multicolumn{2}{|c|}{$\begin{array}{l}\mathrm{THF}, \mathrm{T}\left({ }^{\circ} \mathrm{C}\right) \\
15 \mathrm{~min} \text { then } \mathrm{rt}\end{array}$} \\
\hline $\mathrm{R}$ & $x / y / T$ & Yield(s) (\%) \\
\hline $\mathrm{CN}$ & $3 / 6 /-78$ & $86\left(\mathrm{R}^{\prime}=\mathrm{SiMe}_{3}\right)$ \\
\hline $\mathrm{CN}$ & $2.2 / 10 / 0$ & $65\left(R^{\prime}=\mathrm{SiMe}_{3}\right), 35\left(\mathrm{R}^{\prime}=\mathrm{H}\right)$ \\
\hline $\mathrm{CO}_{2} \mathrm{iPr}$ & $1.2 / 10 /-78$ & $90\left(R^{\prime}=H\right)$ \\
\hline $\mathrm{CO}_{2} \mathrm{Et}$ & $1.2 / 10 /-78$ & $38\left(R^{\prime}=H\right)$ \\
\hline COtBu & $2.2 / 10 /-78$ & $59\left(R^{\prime}=H\right)$ \\
\hline
\end{tabular}

By adding benzonitrile to an excess of LiTMP and chlorotrimethylsilane in THF at $-78{ }^{\circ} \mathrm{C}, 2$-(trimethylsilyl)- and 2,6-bis(trimethylsilyl)benzonitrile formed. By controlling the amount of base, monofunctionalization was observed from isopropyl and, to a lesser extent, sterically less hindered ethyl benzoate; it could be even extended to pivalophenone. By starting from diphenylsulfone, dichlorodimethylsilane also worked as in situ trap to provide the cyclic silane (Scheme 2). ${ }^{9}$

The polyfunctionalization observed above (Table $1 ; \mathrm{R}=\mathrm{CN}$ ), and also evidenced from 1,3-dicyanobenzene and tetraisopropyl 1,2,4,5-benzenetetracarboxylate (Scheme 3), ${ }^{9}$ is probably due to in situ metalation-trapping of an initially formed monosilane.

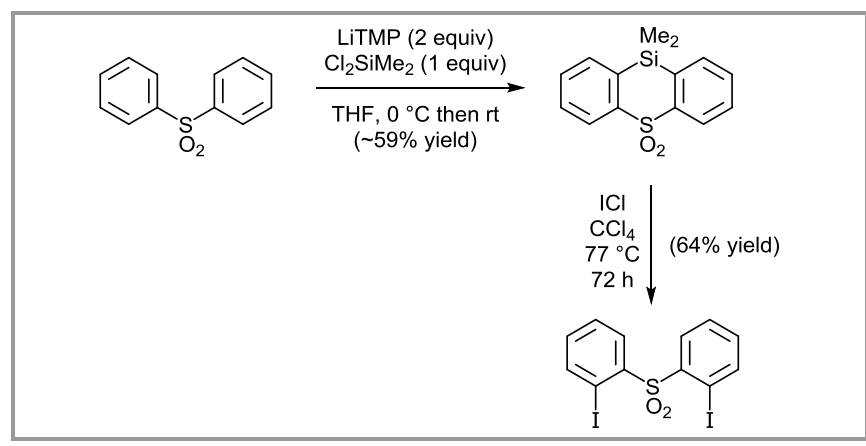

Scheme 2 Functionalization of diphenylsulfone using the LiTMP dichlorodimethylsilane tandem

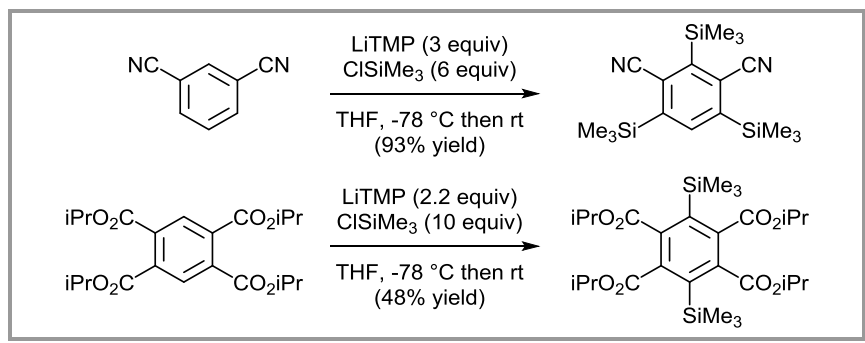

Scheme 3 Functionalization of 1,3-dicyanobenzene and tetraisopropyl 1,2,4,5-benzenetetracarboxylate using the LiTMP-chlorotrimethylsilane pair

Similarly, Luliński and Serwatowski documented in 2003 the double metalation-silylation of 1,4- and 1,2-dibromobenzene by using LiDA in the presence of chlorotrimethylsilane (2 equiv each; Scheme 4). ${ }^{11}$ It is worth noting that, once functionalized at $\mathrm{C2}$, the 6-position of 1,4-dibromobenzene is somewhat protected toward deprotometalation owing to the buttressing effect ${ }^{12}$ exerted by the trimethylsilyl group next to the bromine atom. ${ }^{13}$ Similarly, the lower yield noticed in the double functionalization of 1,2-dibromobenzene is not related to competitive benzyne formation ${ }^{14}$ or halogen 'dance' reaction, ${ }^{15}$ these possibilities being here prevented under in situ trapping. A reaction unfavored at $\mathrm{C} 6$ due to the buttressing effect exerted by the trimethylsilyl present at C3 is more likely to occur.

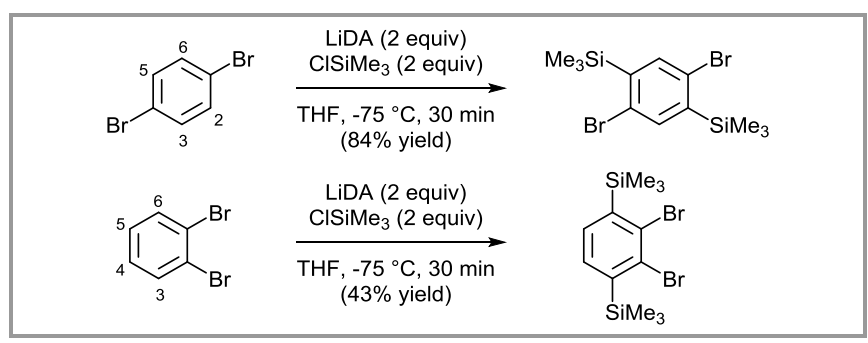

Scheme 4 Double metalation-in situ silylation of 1,4- and 1,2dibromobenzene using the LiDA-chlorotrimethylsilane tandem

In the above examples, if the amount of base is reduced, clean monofunctionalizations are not yet obvious since both the substrates and the monosilylated products share a similar reactivity. ${ }^{11}$ However, the use of an additional bulky substituent can help to control the reaction outcome. Indeed, from 1,2dibromobenzene, a second deprotonation can be completely suppressed in the presence of a substituent at C4. In addition, 
LiTMP was identified as a better base than LiDA to this purpose (Scheme 5).

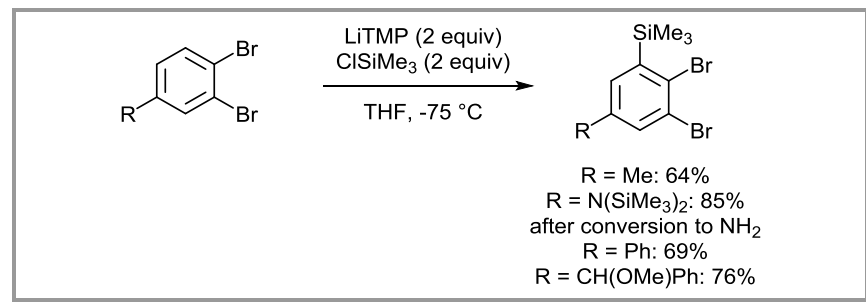

Scheme 5 Single metalation-in situ silylation of 4-substituted 1,2dibromobenzenes using the LiTMP-chlorotrimethylsilane tandem

In the example below reported by Widhalm and co-workers in 2009 , dideprotonation is employed to generate a symmetrical 2,2'-dibromo-3,3'-disilylated binaphthyl from which four different 2,2',3,3'-tetrahalogenated derivatives can be prepared (Scheme 6). ${ }^{16}$

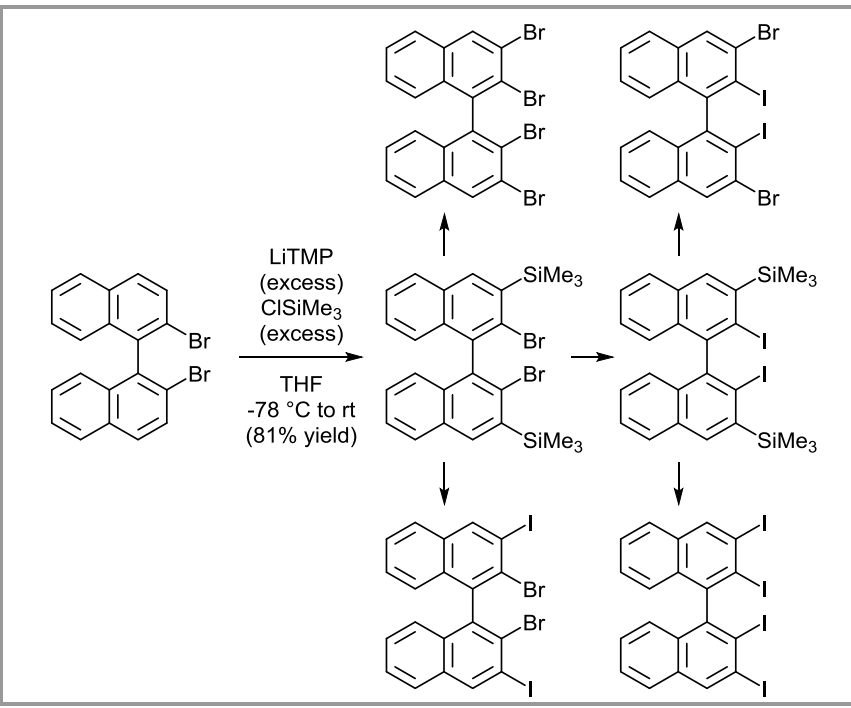

Scheme 6 Synthesis of 2,2',3,3'-tetrahalogenated derivatives from 2,2'dibromo-1,1'-biphenyl using the LiTMP-chlorotrimethylsilane pair

If elimination of lithium bromide is prevented by in situ trapping in the above examples, it is not a universal rule. For example, bromoanisoles cannot undergo LiDA-mediated deprotonation in THF at low temperatures using chlorotrimethylsilane, the insufficient stability of the intermediate 2-bromophenyllithiums leading to benzyne formation. ${ }^{17}$ One possible trick consists of using a remote bromine, which stabilizes the lithio product by electron-withdrawing effect, 18 but the issue is not entirely solved.

In the course of the synthesis of aryne precursors, Mesgar and Daugulis observed in 2016 that chlorodimethylsilane, sterically smaller and more electrophilic than chlorotrimethylsilane, is a more efficient in situ trap for unstable 2-halogenated phenyllithiums. The best results were recorded by mixing the reagents at $-110^{\circ} \mathrm{C}$ before warming (Table 2). ${ }^{19}$

As reported before with esters, there is no need to protect the carboxylic acid function if the chlorotrimethylsilane in situ quench is applied to the deprotolithiation of meta-anisic acid using LiTMP ( 3 equiv) in THF under cryogenic conditions. The trimethylsilyl group thus introduced can act as a protecting group, enabling subsequent functionalization at the 6-position (Scheme 7). ${ }^{20}$ Unlike chlorotrimethylsilane and -triethylsilane, which allowed ortho-phthalic acids to be difunctionalized in the presence of LiTMP (Scheme 8), chlorotriisopropylsilane and tert-butyldimethylsilane are not suitable in situ traps. ${ }^{21}$

Table 2 Functionalization of halogenated benzenes using the LiTMPchlorodimethylsilane tandem

\begin{tabular}{|l|l|l|}
\hline \\
\hline
\end{tabular}

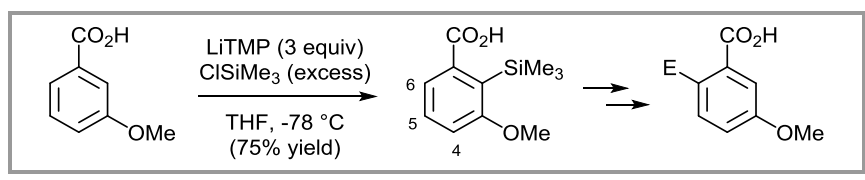

Scheme 7 Functionalization of meta-anisic acid using the LiTMPchlorotrimethylsilane tandem

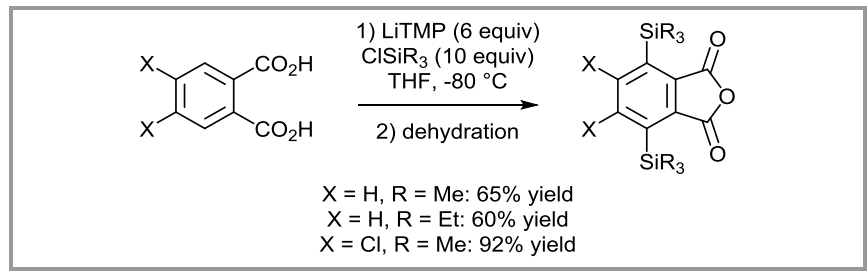

Scheme 8 Difunctionalization of phthalic acids using LiTMP-CISiR 3 pairs

Nitro group is hardly compatible with deprotolithiation due to its possible reduction by electron transfer from the base or the arylmetal. In order to minimize the contact time between nitro 
aromatics and carbon-centered anions, Black and co-workers employed metal amide-chlorotrimethylsilane pairs to attempt the functionalization of 2,4-difluoro-1-nitrobenzene. As shown in Table 3, the best results were observed by using sodium and potassium amides. ${ }^{22}$ The reaction using sodium bis(trimethylsilyl)amide (NaHMDS) was further extended to other sensitive substrates (Table 4). The results show very electron-deficient aromatics are required, suggesting for these substrates a mechanism based on inductive acidification of the adjacent hydrogen rather than on coordination of the base by the directing group. ${ }^{22}$

Table 3 Optimization of 2,4-difluoro-1-nitrobenzene functionalization using metal amide-chlorotrimethylsilane tandems

\begin{tabular}{|c|c|}
\hline Base & Yield(s) (\%) \\
\hline LiDA & 36 \\
\hline LiTMP & $70(75)^{\mathrm{b}}$ \\
\hline LiBSBA & 78 \\
\hline LiHMDS & 100 \\
\hline NaHMDS & 91 \\
\hline KHMDS & ClSiMe $_{3}$ (3 equiv) $-78{ }^{\circ} \mathrm{C}$ \\
\hline
\end{tabular}

${ }^{a}$ Lithium (tert-butyldimethylsilyl)-tert-butylamide. ${ }^{b}$ Using chlorotrimethylstannane as in situ trap.

Table 4 Functionalization of nitrobenzenes using the NaHMDSchlorotrimethylsilane tandem

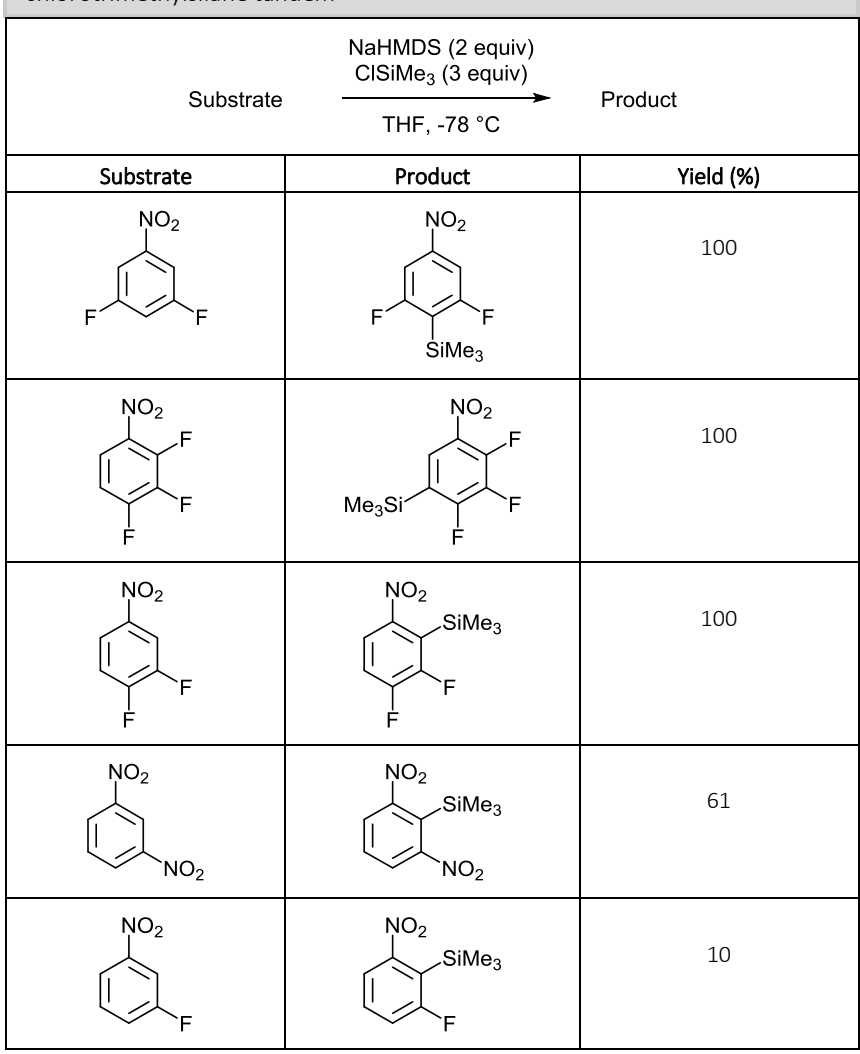

Beside its usefulness to avoid side reactions of sensitive substrates, in situ trapping can also be at the origin of an altered regioselectivity. For example, whereas 2-bromopyridine is selectively functionalized at C3 upon treatment with LiDA in
THF at low temperatures before electrophilic trapping, ${ }^{23}$ mixtures of 3-silylated (thermodynamic, main) and 4-silylated (kinetic, minor) products are obtained in the presence of chlorotrimethylsilane. ${ }^{24} \mathrm{~A}$ kinetic lithio compound at C6 is even intercepted by the in situ trap (65\% yield) when LiTMP is employed in diethyl ether at $-78^{\circ} \mathrm{C} . .^{25}$

In the same vein, Snieckus, Mortier and co-workers documented an optional site selectivity for the functionalization of $\mathrm{N}, \mathrm{N}$ dialkylated biphenyl-2-carboxamides depending on if the electrophile is in situ or not. For example, $N, N$-diethylbiphenyl2-carboxamide is silylated ortho to the functional group by using the in situ quench protocol whereas the initially formed lithio compound equilibrates with the 2'-lithiobiphenyl-2carboxamide without. The latter is rapidly intercepted by the carboxamide, here also playing the role of internal trap (Scheme 9). ${ }^{26}$
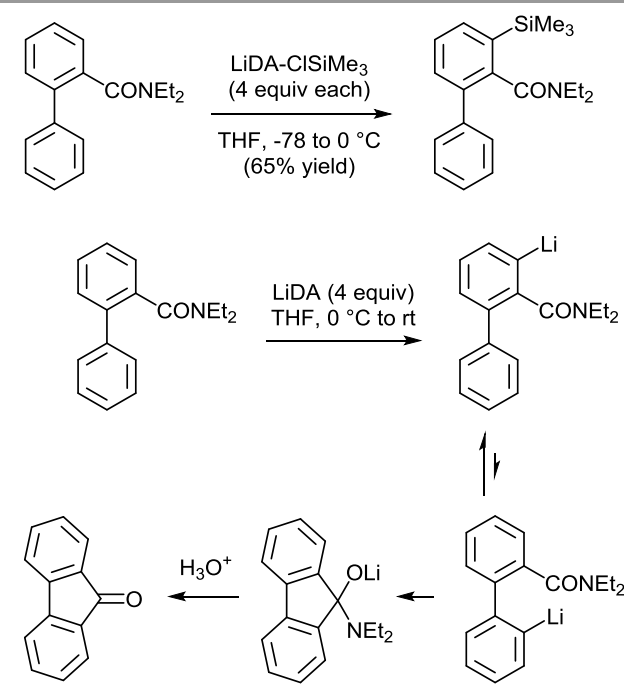

Scheme 9 Functionalization of $\mathrm{N}, \mathrm{N}$-diethylbiphenyl-2-carboxamide using LiDA with and without in situ chlorotrimethylsilane

Simpkins and co-workers used in 1994 a chiral lithium amide to attempt the enantioselective deprotonation of tricarbonyl $\left(\eta^{6-}\right.$ arene)chromium complexes (Table 5). ${ }^{27}$ The higher levels of asymmetric induction were recorded by using chlorotrimethylsilane as internal quench $(0.04 \mathrm{M})$. The lower enantioselectivities noticed with external quench reactions (73\% ee if the trapping is performed after $0.5 \mathrm{~min}, 52 \%$ after 1 h, $25 \%$ after $3 \mathrm{~h}$ ) were rationalized by an intermolecular equilibration between substrate and lithiated derivative. In situ trapping here helped in achieving a kinetically controlled reaction giving chiral, nonracemic tricarbonyl $\left(\eta^{6}\right.$ arene)chromium complexes. ${ }^{27-28}$

This study was extended to substituted ferrocenes. Although diphenylphosphinylferrocene proved to be the best candidate, the silylated derivative was isolated in $95 \%$ yield but only $54 \%$ ee by using the method depicted in Table $5 .^{29}$

Finally, because it provides irreversible conditions, the LiTMPchlorotrimethylsilane pair was used to evaluate the relative reaction rates (kinetic acidities) of different substituted benzenes, and thus the ability of the substituents to enhance the proton mobility at the transition state. ${ }^{30}$ 
Table 5 Enantioselective functionalization of tricarbonyl $\left(\eta^{6}\right.$-arene)chromium complexes using a chiral lithium amide under kinetic control

\begin{tabular}{|c|c|c|}
\hline & $\begin{array}{c}\mathrm{Ph}_{\mathrm{LiSh}} \\
\mathrm{CHF},-78{ }^{\circ} \mathrm{C}\end{array}$ & \\
\hline$R$ & Yield (\%) & ee (\%) \\
\hline $\mathrm{OMe}$ & 83 & 84 \\
\hline OEt & 82 & 81 \\
\hline $\mathrm{OiPr}$ & 65 & 90 \\
\hline $\mathrm{OtBu}$ & 0 & - \\
\hline $\mathrm{OCH}_{2} \mathrm{OMe}$ & 76 & 80 \\
\hline $\mathrm{CH}\left(\mathrm{OCH}_{2} \mathrm{CH}_{2} \mathrm{O}\right)$ & 36 & 84 \\
\hline $\mathrm{Cl}$ & 27 & 51 \\
\hline $\mathrm{F}$ & 57 & 16 \\
\hline $\mathrm{CONiPr}_{2}$ & 87 & 48 \\
\hline $\mathrm{N}(\mathrm{Me}) \mathrm{CO}$ tBu & 65 & 44 \\
\hline
\end{tabular}

\section{Boron-based in situ traps}

Esters are considered as better directing groups than amides in deprotometalations; nevertheless, their use was delayed because of their low compatibility with organolithiums. ${ }^{10}$ Smooth bases such as $\mathrm{Mg}(\mathrm{TMP})_{2}$ were first evaluated in THF for the functionalization of methyl benzoate, but the reactions required an excess of reagent. ${ }^{2}$ Inspired by the study of Krizan and Martin (Table 1), ${ }^{9}$ Caron and Hawkins demonstrated in 1998 that LiDA can be an efficient kinetic base, compatible with both chlorotrimethylsilane and triisopropylborate. ${ }^{31}$ In the presence of the latter, various neopentyl benzoates were converted into the corresponding 2-boronyl derivatives (isolated as their diethanolamine complexes) upon treatment with LiDA in THF (Table 6). Except in the case of the 4-fluoro derivative, the function was introduced regioselectively at the position adjacent to the ester. ${ }^{31}$

Table 6 Functionalization of neopentyl benzoate using the LiDAtriisopropylborate tandem

\begin{tabular}{|c|c|c|c|}
\hline & \multicolumn{2}{|c|}{$\begin{array}{l}\text { 1) LiDA (x equiv) } \\
\begin{array}{l}\text { B(OiPr) } \\
\text { THF, }\left(2.6 \text { equiv) }\left({ }^{\circ} \mathrm{C}\right) \text {, time }\right.\end{array} \\
\underset{\text { 2) diethanolamine }}{\longrightarrow}\end{array}$} & \multirow[b]{2}{*}{ Yield $(\%$} \\
\hline$R$ & $x$ & $\mathrm{~T}\left({ }^{\circ} \mathrm{C}\right)$, time $(\mathrm{min})$ & \\
\hline $4-B r$ & 1.1 & $-78,5$ & 84 \\
\hline $4-\mathrm{CF}_{3}$ & 1.1 & 0,30 & 74 \\
\hline 4-OMe & 1.6 & 0,180 & 70 \\
\hline $4-F$ & 1.1 & $-78,15$ & $52^{a}$ \\
\hline $4-\mathrm{Cl}$ & 1.2 & $-78,10$ & 90 \\
\hline $2-B r$ & 1.2 & $-78,10$ & 88 \\
\hline $2-\mathrm{CF}_{3}$ & 1.2 & $-78,60$ & 93 \\
\hline $3-F$ & 1.2 & -78 to $-40,180$ & 90 \\
\hline
\end{tabular}

${ }^{a}$ Competitive metalation next to fluorine was noticed.

By switching from LiDA to LiTMP, Vedsø and co-workers accessed a large range of 2-substituted arylboronic esters, appropriate partners in Suzuki-type cross-coupling. The reaction using hindered and more basic LiTMP $\left(\mathrm{p} K_{\mathrm{a}}=37.3\right.$ for 2,2,6,6-tetramethylpiperidine against 35.7 for diisopropylamine) ${ }^{32}$ is no more limited to the neopentyl ester function, but works with simpler ethyl benzoate, as well as benzonitrile, fluorobenzene and even the less activated chlorobenzene (Table 7). ${ }^{33}$ It is worth noting that although 2chlorophenyllithium can only be accumulated at $-100{ }^{\circ} \mathrm{C}, 34$ in situ trapping at higher temperature bypasses subsequent elimination giving benzyne. ${ }^{14}$

That LiTMP is more powerful than LiDA was also demonstrated by Kristensen and co-workers for the lithiation-in situ borylation of cyanopyridines (Figure 1$)^{35}$ and in the course of a study on the deprotometalation of substituted benzonitriles. ${ }^{4}$ By this way, nitrile was compared to different directing groups (DG) already used in deprotometalation reactions (Table 8). ${ }^{4}$

Table 7 Functionalization of ethyl benzoate, benzonitrile, fluorobenzene and chlorobenzene using lithium amide-triisopropylborate tandems

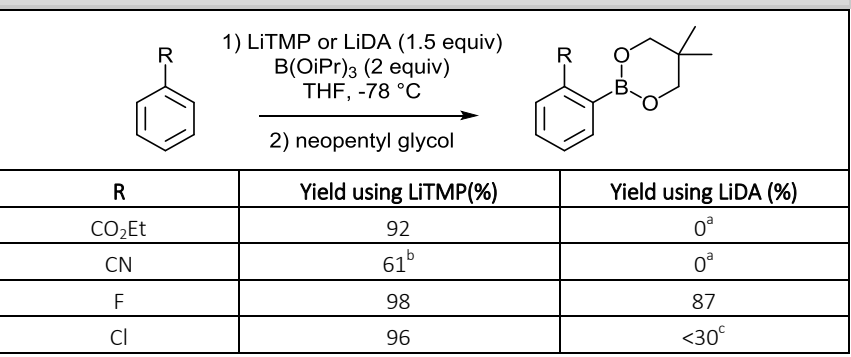

${ }^{a}$ Only $N, N$-diisopropylbenzamide formed. ${ }^{b}$ Benzamide resulting from the addition of LiTMP to benzonitrile formed in $20-25 \%$ yield. ${ }^{C}$ Numerous impurities present.

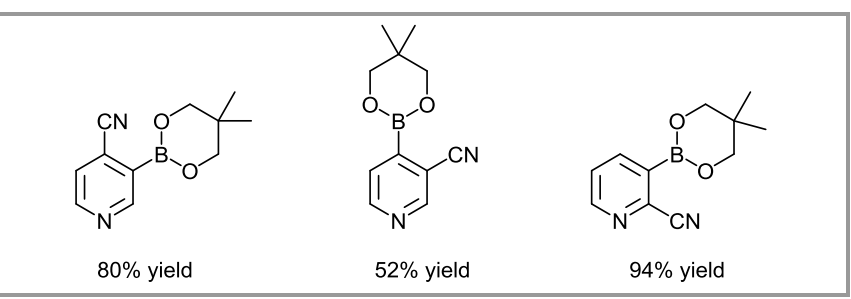

Figure 1 Borylated cyanopyridines synthesized by using (i) LiTMP-B(OiPr) $)_{3}(1.2$ equiv) in THF at $-78^{\circ} \mathrm{C}$ and (ii) neopentylglycol

Table 8 Comparison of $\mathrm{CN}$ to other metalation directing groups (DG) using in situ trapping

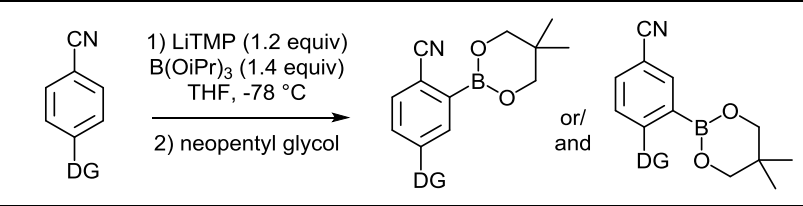

\begin{tabular}{|c|c|c|}
\hline DG & Ratio $^{a}$ & Yield (\%) \\
\hline $\mathrm{OMe}$ & $30 / 70(25 / 25)^{b}$ & 96 \\
\hline $\mathrm{CF}_{3}$ & $100 / 0(40 / 0)^{b}$ & 99 \\
\hline $\mathrm{F}$ & $40 / 60(35 / 45)^{b}$ & 94 \\
\hline $\mathrm{Cl}$ & $93 / 7(60 / 35)^{b}$ & 99 \\
\hline $\mathrm{Br}$ & $90 / 10(70 / 25)^{b}$ & 98 \\
\hline \multicolumn{3}{|c|}{$\begin{array}{l}\text { 1) } \mathrm{LiTMP} \text { (1.2 equiv) } \\
\mathrm{B}(\mathrm{OiPr})_{3}(1.4 \text { equiv) } \\
\underset{\mathrm{THF},-78{ }^{\circ} \mathrm{C}}{\stackrel{\mathrm{T} \text { neopentyl glycol }}{\longrightarrow}}\end{array}$} \\
\hline DG & Ratio & Yield (\%) \\
\hline $\mathrm{OMe}$ & $100 / 0$ & 96 \\
\hline $\mathrm{CF}_{3}$ & $0 / 100$ & 98 \\
\hline $\mathrm{F}$ & $100 / 0$ & 96 \\
\hline $\mathrm{Cl}$ & $100 / 0$ & c \\
\hline $\mathrm{Br}$ & $100 / 0$ & 96 \\
\hline
\end{tabular}




\begin{tabular}{|c|c|c|}
\hline \multicolumn{2}{|c|}{$\begin{array}{c}\text { 1) LiTMP (1.2 equiv) } \\
\mathrm{B}(\mathrm{OiPr})_{3}(1.4 \text { equiv) } \\
\mathrm{THF},-78{ }^{\circ} \mathrm{C}\end{array}$} \\
\hline 2) neopentyl glycol \\
\hline $\mathrm{DG}$ & Ratio & 96 \\
\hline $\mathrm{OMe}$ & $100 / 0$ & 99 \\
\hline $\mathrm{CF}_{3}$ & $100 / 0$ & 99 \\
\hline $\mathrm{F}$ & $40 / 60$ & 96 \\
\hline $\mathrm{Cl}$ & $95 / 5$ & 97 \\
\hline $\mathrm{Br}$ & $98 / 2$ & Yield (\%) \\
\hline
\end{tabular}

${ }^{\mathrm{a}}$ The values in brackets are those using LiDA instead of LiTMP. ${ }^{\mathrm{b}}$ The rest is the 4substituted $\mathrm{N}, \mathrm{N}$-diisopropylcarboxamide. ${ }^{\mathrm{C}}$ Impossible to isolate as a single entity.

Snieckus and co-workers reported in 2007 a one-pot deprotometalation-in situ boronation-oxidation to generate hydroxy derivatives of sensitive $\mathrm{N}, \mathrm{N}$-diethylpicolinamides. The process does not require cryogenic temperatures and works in high yields (Scheme 10). Pinacolate and boroxazine derivatives of the different $\mathrm{N}, \mathrm{N}$-diethylpyridinecarboxamides, $\mathrm{N}, \mathrm{N}$-diethyl3-pyridinesulfonamide and -carbamate, and 3-fluoropyridine were similarly prepared and converted by Suzuki coupling. ${ }^{36}$

$$
\mathrm{R}=\mathrm{H}, \mathrm{CO}_{2} \mathrm{tBu}, \mathrm{CH}_{2} \mathrm{OTBS}
$$

\section{Scheme 10 Picolinamide deprotonation-in situ boronation-oxidation}

Morpholine amides are safer and less expensive alternatives to Weinreb amides, which are known as acylation reagents of organometallic compounds. Kristensen and co-workers documented in 2017 the functionalization of various aromatic morpholine amides by using in situ borylation. When combined with triisopropyl borate, LiTMP proved superior than LiDA for this purpose (Table 9). ${ }^{37}$

Table 9 Borylation of morpholine amides using the tandem LiTMP (1.2 equiv)$\mathrm{B}(\mathrm{OiPr})_{3}$ (1.4 equiv)

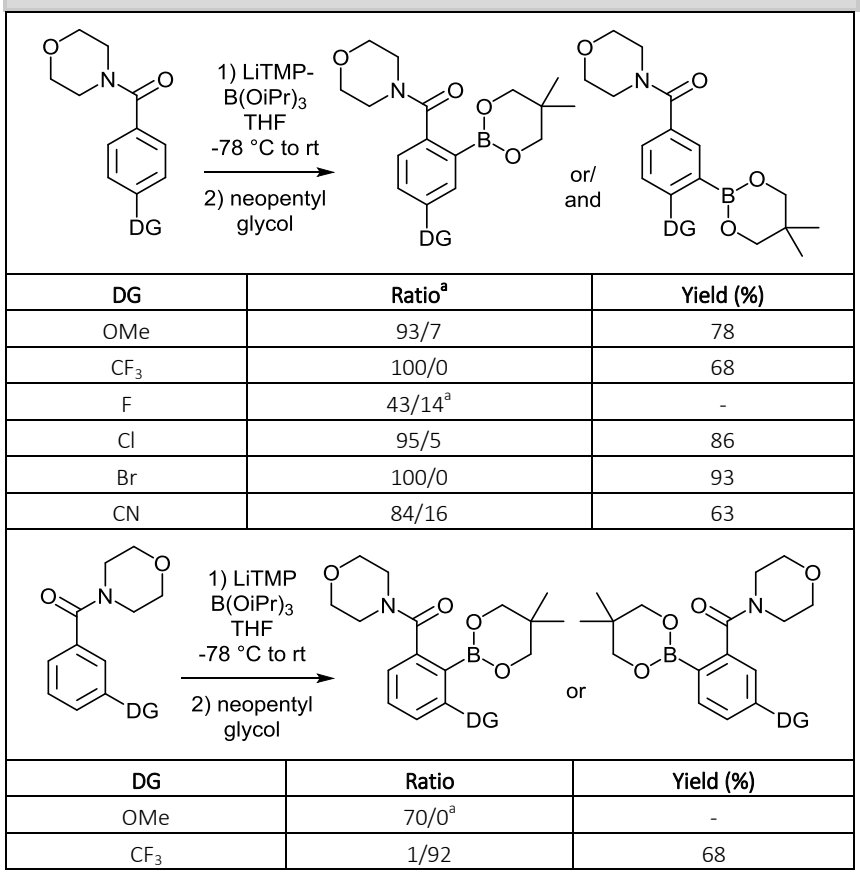

\begin{tabular}{|c|c|c|}
\hline $\mathrm{F}$ & $5 / 5^{a}$ & - \\
\hline $\mathrm{Cl}$ & $100 / 0$ & 72 \\
\hline $\mathrm{CN}$ & $50 / 50$ & 67 \\
\hline & & \\
\hline DG & Ratio & Yield (\%) \\
\hline $\mathrm{OMe}$ & $0 / 0^{a}$ & - \\
\hline $\mathrm{CF}_{3}$ & $95 / 0$ & 84 \\
\hline $\mathrm{F}$ & $73 / 27$ & 59 \\
\hline $\mathrm{Cl}$ & $100 / 0$ & 78 \\
\hline $\mathrm{Br}$ & $100 / 0$ & 90 \\
\hline $\mathrm{CN}$ & $100 / 0$ & 80 \\
\hline
\end{tabular}

${ }^{\mathrm{a}}$ The rest is starting material.

In the azine series, boron-based in situ traps can also activate the substrates toward deprotonation and even control the regioselectivity. In this way, Knochel and co-workers employed in 2010 ClMgTMP.LiCl in the presence of boron trifluoride etherate in THF to chemo- and regioselectively deprotonate pyridines and related $N$-heterocycles (e.g. quinoline, Scheme 11) which are substrates prone to nucleophilic attacks. ${ }^{38}$ Interestingly, optional site selectivity could be reached from various nitrogen-containing substrates depending on if boron trifluoride is present or absent from the reaction mixture (Figure 2). ${ }^{38 a, 38 c}$

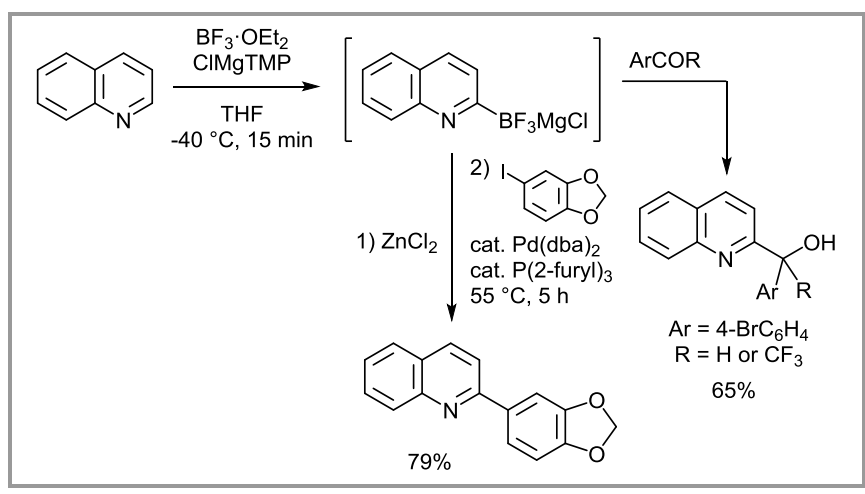

Scheme 11 Functionalization of quinoline using CIMgTMP.LiCl in the presence of $\mathrm{BF}_{3} \cdot \mathrm{Et}_{2} \mathrm{O}$

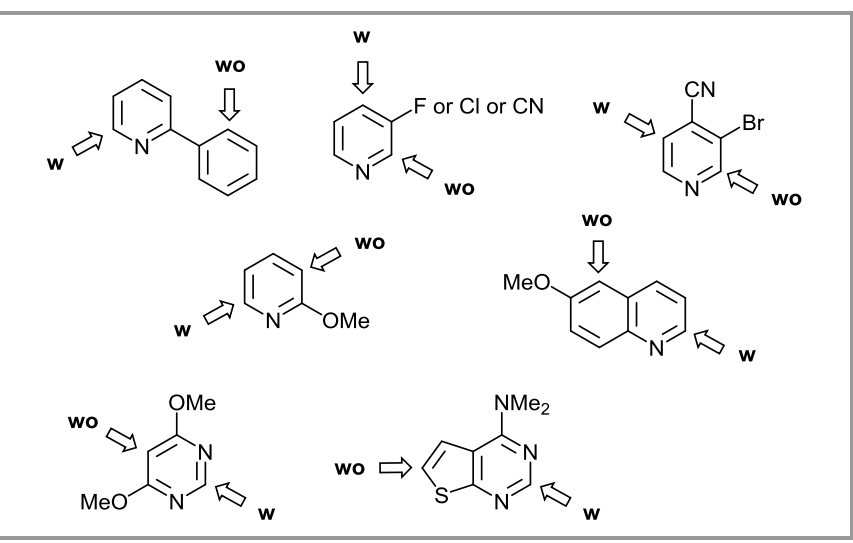

Figure 2 Regioselectivity of the functionalization of azines and diazines using

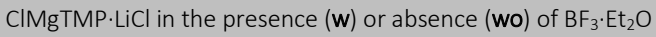




\section{Zinc-based in situ traps}

In the course of the search of new lithium-zinc bases, Mongin and co-workers generated 1:1 LiTMP-Zn(TMP) 2 by reacting $\mathrm{ZnCl}_{2} \cdot$ TMEDA (TMEDA $=N, N, N^{\prime}, N^{\prime}$-tetramethylethylenediamine) with LiTMP (3 equiv). ${ }^{39}$ Due to steric incompatibility, formation of the lithium zincate LiZn(TMP) $)_{3}$ is prohibited. This lack of cocomplexation between both amides is of interest, the combination working as a base, LiTMP, in the presence of an in situ trap, $\left(\mathrm{Zn}(\mathrm{TMP})_{2}\right){ }^{40}$ This basic mixture is thus capable of deprotonating chemoselectively a large range of sensitive aromatic substrates including heterocycles.

Lithiation of bare diazines represents a difficult task due to the low LUMO levels of these substrates, and thus their sensitivity to nucleophilic attacks. With pyrazine and pyridazine, the reaction is possible using LiTMP in excess, as long as very short reaction times at very low temperatures are respected. In contrast, metalation of pyrimidine can only be accomplished using the in situ trapping technique. ${ }^{41}$ 1:1 LiTMP-Zn(TMP) $)_{2}$ could be used in THF at room temperature or above to lead, after iodolysis, to the expected iodides in medium yields (Scheme 12). ${ }^{42}$

1) LiTMP-Zn(TMP)
$(0.5$ equiv each)
2-N (reflux): $66 \%$ yield in the presence of TMEDA (5 equiv)
3- $\mathrm{N}(\mathrm{T}=25): 57 \%$ yield
4- $\mathrm{N}(\mathrm{T}=25): 59 \%$ yield

Scheme 12 Deprotonation-iodolysis of bare diazines using 1:1 LiTMP$\mathrm{Zn}(\mathrm{TMP})_{2}$ (generated from $\mathrm{ZnCl}_{2} \cdot$ TMEDA and LiTMP in a 1:3 ratio)

Similarly, deprotolithiation of 3-bromo- and 3-chloropyridine using lithium amides have to be carried out at $-78{ }^{\circ} \mathrm{C}$ in order to avoid nucleophilic attacks onto the $\pi$-deficient ring and elimination of lithium halide giving pyridyne. ${ }^{23}$ In the presence of $\mathrm{Zn}(\mathrm{TMP})_{2}$, LiTMP can be used at room temperature; the kinetic 2-metalated compounds can be intercepted by iodolysis whereas they equilibrate to afford the more stable 4-lithio derivatives in the absence of in situ trap (Scheme 13).43

$\begin{gathered}\text { 1) LiTMP-Zn(TMP) } \\ \text { (0.5 equiv each) } \\ \text { THF, rt, } 2 \mathrm{~h}\end{gathered}$
2) $\mathrm{I}_{2, \mathrm{THF}}$
$\mathrm{X}=\mathrm{Br}: 83 \%$ yield (13\% of the 4 -iodo derivative)
$\mathrm{X}=\mathrm{Cl} \%$ yield (4\% of the 2,4 -diodo derivative)

Scheme 13 Deprotonation-iodolysis of 3-bromo- and 3-chloropyridine using 1:1 LiTMP-Zn $(T M P)_{2}$ (generated from $\mathrm{ZnCl}_{2} \cdot$ TMEDA and LiTMP in a 1:3 ratio)

The kinetic deprotonation sites are in general next to heteroatoms able to coordinate metals (lowering the $\mathrm{p} K_{\mathrm{a}}$ values upon coordination by nitrogen). As a consequence, $\mathrm{N}$-(3pyridyl)pyrrole and -indole are for example deprotolithiated next to the pyridine nitrogen before interception by $\mathrm{Zn}(\mathrm{TMP})_{2}$ (Scheme 14). ${ }^{4}$

Whereas LiTMP is barely employed to deprotometalate benzenes, 1:1 LiTMP-Zn(TMP) 2 can be used for both aromatic heterocycles benefiting from relatively acidic hydrogens (Scheme 12 and 13; Figure 3, top) and less activated substrates such as anisole and naphthalenes (Figure 3 , bottom). ${ }^{45}$

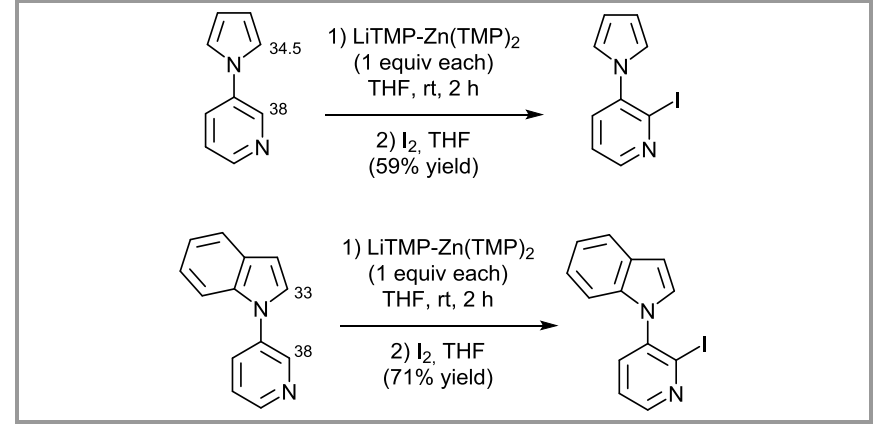

Scheme 14 Deprotonation-iodolysis of $N$-(3-pyridyl)pyrrole and -indole (selected $\mathrm{pK} K_{\mathrm{a}}$ values are given) using 1:1 LiTMP-Zn(TMP) ${ }_{2}$ (generated from $\mathrm{ZnCl}_{2} \cdot$ TMEDA and LiTMP in a 1:3 ratio)

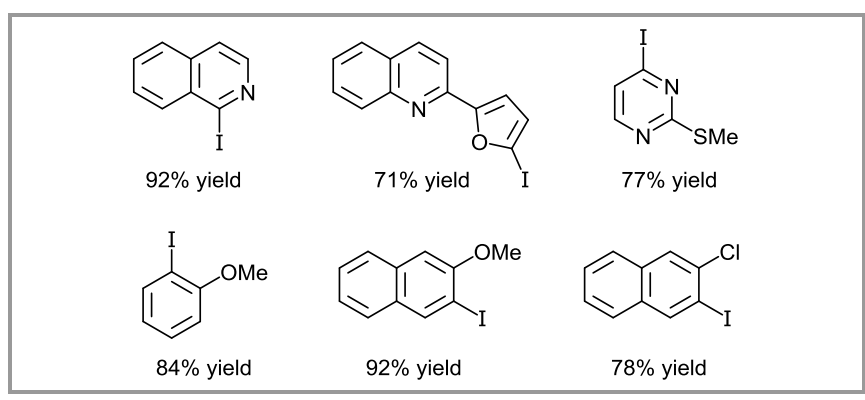

Figure 3 lodinated products synthesized by using 1:1 LiTMP-Zn(TMP $)_{2}$ (generated from $\mathrm{ZnCl}_{2} \cdot$ TMEDA and LiTMP in a 1:3 ratio)

Ferrocenes bearing electrophilic functional groups such as carboxamides, nitrile and esters can undergo a similar treatment at room temperature to provide, after subsequent trapping, either the 2-iodo derivatives or the Negishi-type coupling products. From bromoferrocene, the recorded result evidenced a competitive halogen 'dance' 15 at this temperature (Table 10). ${ }^{46}$

Table 10 Deprotonation followed by iodolysis or Negishi-type coupling of ferrocenes bearing functional groups (FG) using 1:1 LiTMP-Zn(TMP) $)_{2}$ (generated from $\mathrm{ZnCl}_{2} \cdot T M E D A$ and LiTMP in a 1:3 ratio)

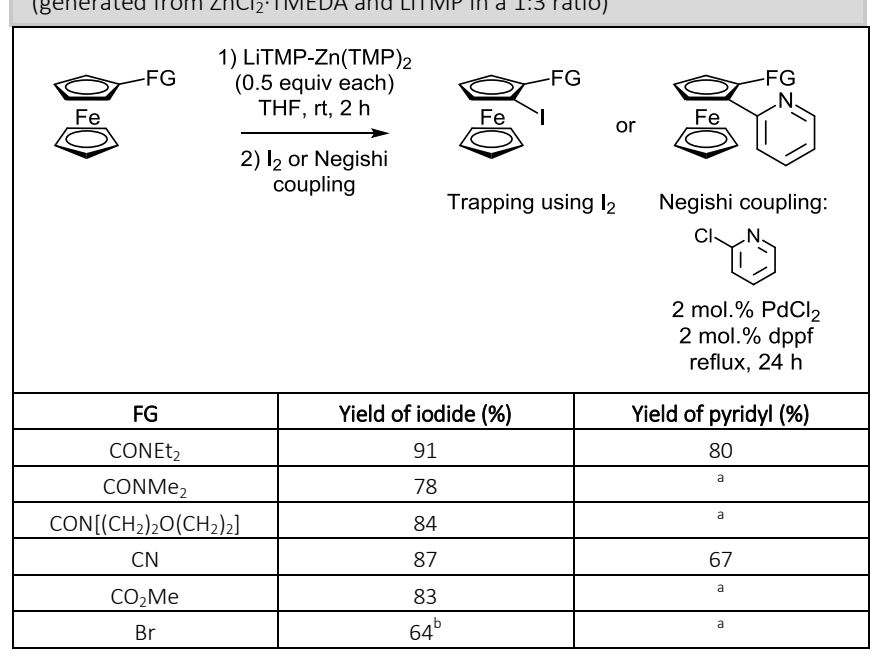

${ }^{a}$ Reaction not attempted. ${ }^{b}$ 1-Bromo-3-iodoferrocene also isolated in 7\% yield.

In an attempt to enantioselectively prepare 2-functionalized methyl ferrocenecarboxylates, Mongin and co-workers mixed in THF the substrate with the putative zinc diamide (used as in situ trap) coming from bis[(S)-1-phenylethyl]amine before adding lithium bis[(S)-1-phenylethyl]amide. When the reaction was 
carried out at $-78{ }^{\circ} \mathrm{C}$ for $24 \mathrm{~h}$ before iodolysis, the expected iodide was obtained in a moderate $50 \%$ yield (due to remaining starting material) but with an $80 \%$ ee (Scheme 15). ${ }^{47}$ Recourse to sugar-derived ferrocene esters possessing chiral directing groups, either combined to chiral lithium amides as above or with 1:1 LiTMP-Zn(TMP)2, proved to be more promising. 48

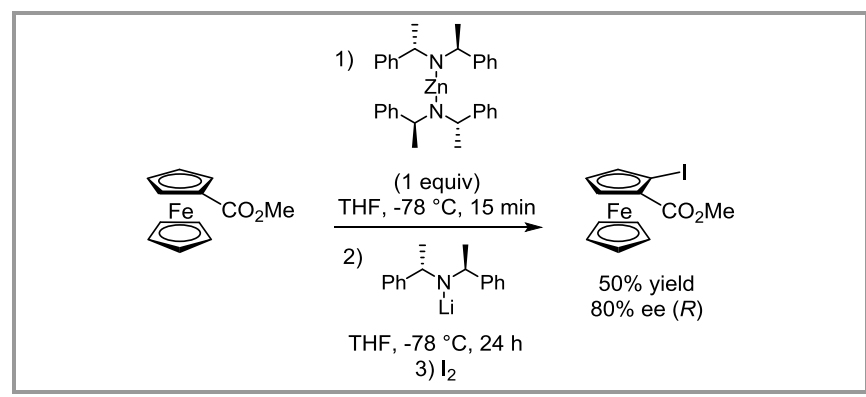

Scheme 15 Enantioselective functionalization of methyl ferrocenecarboxylate by metalation and in situ 'trans-metal trapping' using chiral metal amides

Eaton and co-workers showed in the eighties that LiTMP can be used in the presence of mercury chloride to more efficiently perform amide-directed cubane ${ }^{49}$ and cyclopropane ${ }^{50}$ deprotonation. The idea was to make use of the small amount of organolithium in equilibrium with the starting material, and to use mercury salts as in situ trap to shift the lithiation equilibrium toward the aryllithium. It is worth noting that the obtained organomercury chloride can be converted either to an organolithium (using methyllithium) or -magnesium (using methylmagnesium bromide) by reverse transmetalation. ${ }^{51}$

The presence of zinc chloride, cadmium chloride, chlorotrimethylstannane or chlorotrimethylsilane also allows cubanes to react (mono- or dideprotonation), but less efficiently than mercury chloride (dideprotonation). ${ }^{49 \mathrm{~b}}$ However, reactions to access less toxic organometals such as organozincs can be envisaged from more reactive substrates such as activated benzenes and aromatic heterocycles. In this way, Knochel and co-workers performed in $2009 \mathrm{Mg}(\mathrm{TMP})_{2} \cdot 2 \mathrm{LiCl}$-triggered room temperature deprotonations using zinc chloride as in situ trap to functionalize numerous substrates prone to nucleophilic attacks (e.g. quinoxalines; Scheme 16). In addition to its in situ trap role, zinc chloride can activate the aromatic substrate toward metalation by coordination. ${ }^{52}$ The protocol also avoided aryne formation in the course of the deprotometalation of 1,4dibromobenzene. ${ }^{53}$

The same authors evidenced in 2013 a more efficient pair. By combining ClMgTMP. $\mathrm{LiCl}$ with zinc chloride in the presence of lithium chloride (more soluble), they observed a metalation up to 50 times faster than using single ClMgTMP. $\mathrm{LiCl}$ for $10-15^{\circ} \mathrm{C}$ temperature increase. The procedure tolerates the presence of highly sensitive functional groups such as an aldehyde or electron-deficient heterocycles (Table 11). ${ }^{54}$

Toward indazoles, this combination proved more powerful than 1:1 LiTMP-Zn(TMP) 2 as the competitive ring opening reaction noticed with the latter ${ }^{55}$ can be avoided using the former. ${ }^{54}$

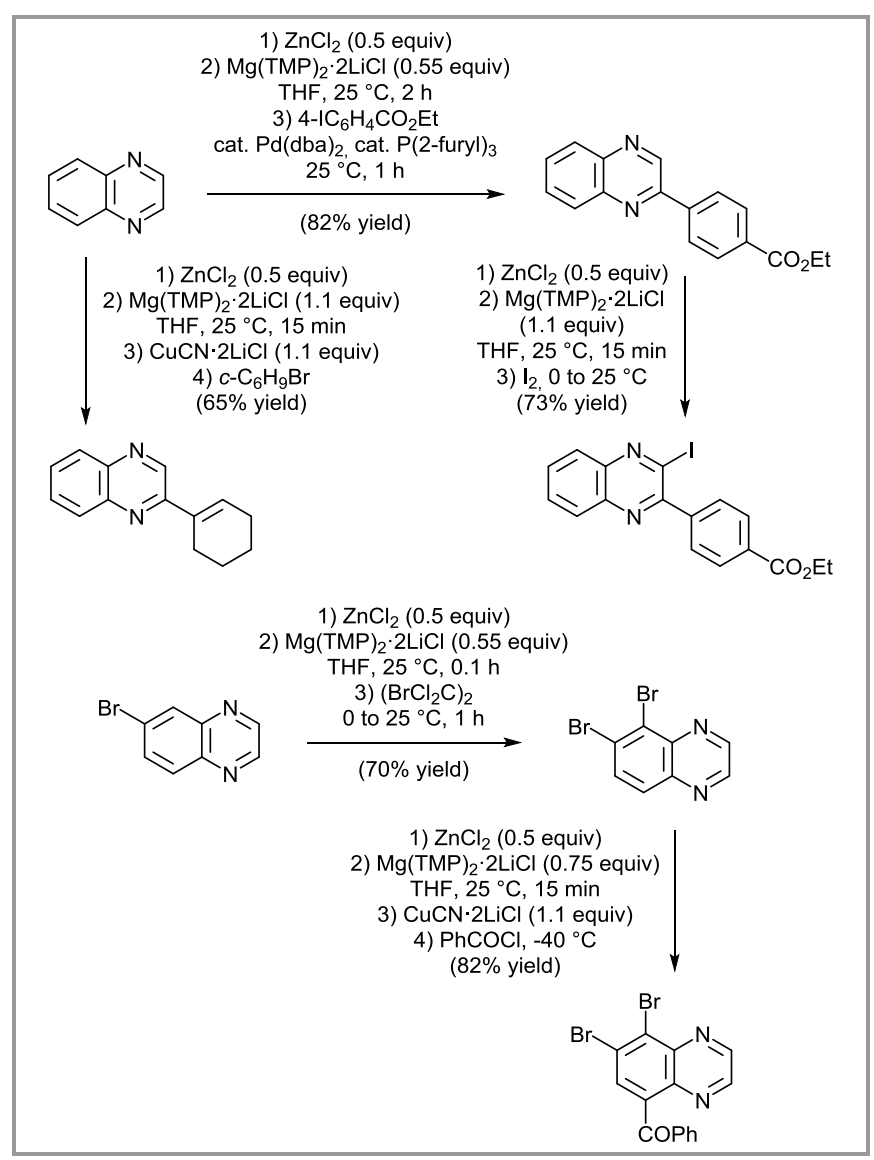

Scheme 16 Functionalization of quinoxalines using $\mathrm{Mg}(\mathrm{TMP})_{2} \cdot \mathrm{LiCl}$ in the presence of zinc chloride

Table 11 Functionalization of sensitive aromatic substrates (Ar-H) using $\mathrm{CIMgTMP} \cdot \mathrm{LiCl}$ in the presence of $\mathrm{ZnCl}_{2} \cdot \mathrm{LiCl}$ or $\mathrm{ZnCl}_{2} \cdot 2 \mathrm{LiCl}$

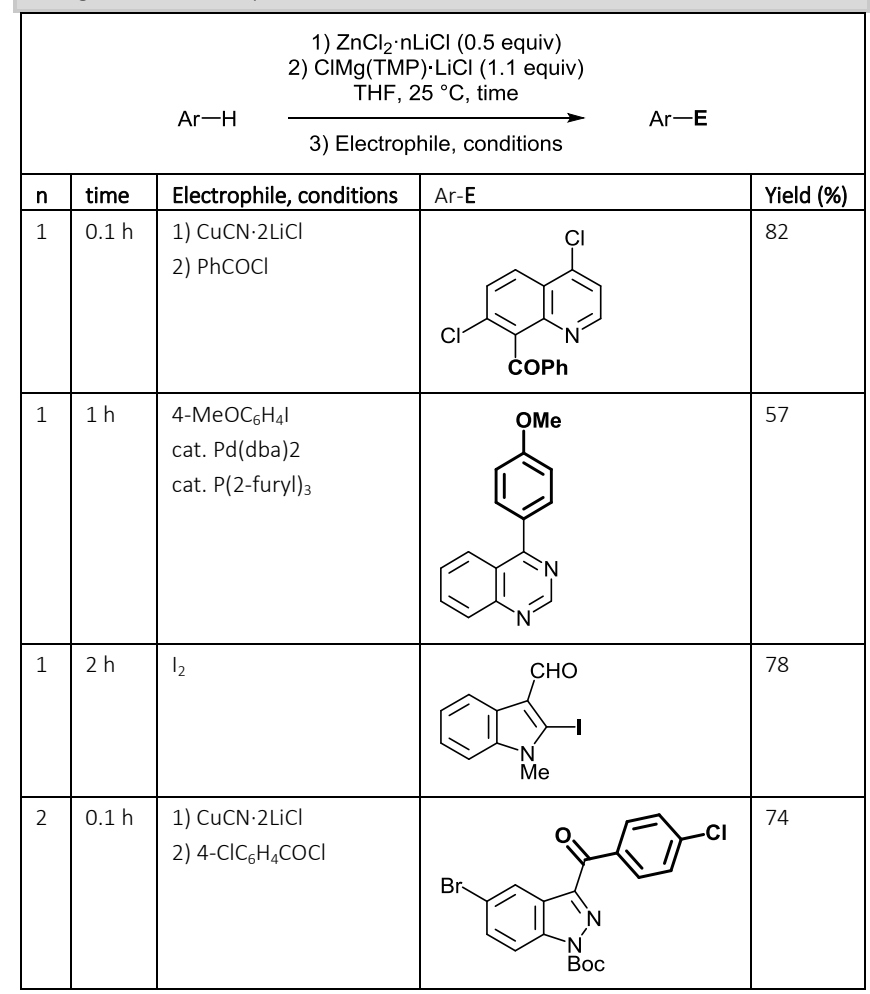


In 2014, optional site selectivity proved possible from various activated aromatic compounds by using either ClM(TMP) $\cdot \mathrm{LiCl}$ ( $\mathrm{M}=\mathrm{Zn}$ or $\mathrm{Mg}$; deprotonation at the most acidic site) or LiTMP (1.5 equiv) in tandem with $\mathrm{ZnCl}_{2} \cdot 2 \mathrm{LiCl}$ (1.1 equiv) at low temperatures (kinetic metalation). The method can be applied to substrates not metalated by ClMgTMP.LiCl at low temperatures, and for which metalation with LiTMP is faster than the transmetalation of LiTMP to ClZnTMP.LiCl. A few examples are given in Scheme 17. According to the authors, deprotolithiation proceeds at least six times faster than the transmetalation of the base by the metal salt. ${ }^{56}$

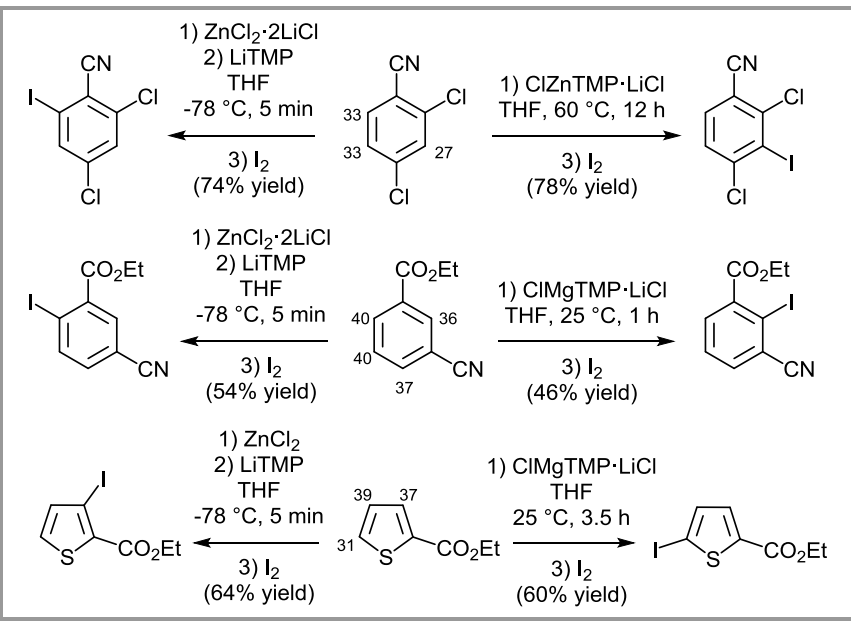

Scheme 17 Regioselectivity of the functionalization of aromatic compounds $\left(\mathrm{p} K_{\mathrm{a}}\right.$ values are given) by using either CIM(TMP). LiCl $(\mathrm{M}=\mathrm{Zn}$ or $\mathrm{Mg})$ or LiTMP in tandem with $\mathrm{ZnCl}_{2} \cdot 2 \mathrm{LiCl}$ at low temperatures

The good solubility of $\mathrm{ZnCl}_{2}$.TMEDA in THF led Erb, Mongin and co-workers to employ it as in situ trap in tandem with LiTMP. Except from 2-benzoylthiophene, performing the reactions in THF at $-55{ }^{\circ} \mathrm{C}$ allowed various aromatic ketones to be regioselectively functionalized next to the functional group (Table 12). ${ }^{57}$ Although $\mathrm{ZnCl}_{2} \cdot$ TMEDA is an efficient in situ trap for most of the substrates, it shows limitations in the LiTMPmediated deprotonation of fluorenone. Indeed, in this case, the corresponding iodide is isolated in a moderate $52 \%$ yield due to the concomitant formation of the alcohol resulting from the intermolecular addition of the lithio compound to the ketone (which acts as in situ trap) (Scheme 18). This alcohol becomes the only isolated product by carrying out the reaction using 1:1 LiTMP-Zn(TMP) 2 at room temperature. ${ }^{57-58}$

Eaton and Martin showed in 2008 that the LiTMP- $\mathrm{HgCl}_{2}$ pair can be employed to obtain the 2,6-dimercurated derivatives of $\mathrm{N}, \mathrm{N}$ diethylbenzamide, isopropyl benzoate, benzonitrile and chlorobenzene, the intermediate 2-mercurated also being a suitable candidate for deprotolithiation-in situ trapping. Because the mercurated aromatics can be intercepted by a limited number of electrophiles (e.g. bromine and iodine), the authors converted the 2,6-dimercurated $N, N$-diethylbenzamide into the corresponding dilithio compound by using butyllithium (reverse transmetalation) and made by this way the quenching possible with deuterated methanol and iodomethane. ${ }^{59}$
Table 12 Functionalization of aromatic ketones using LiTMP in the presence of $\mathrm{ZnCl}_{2} \cdot \mathrm{TMEDA}$

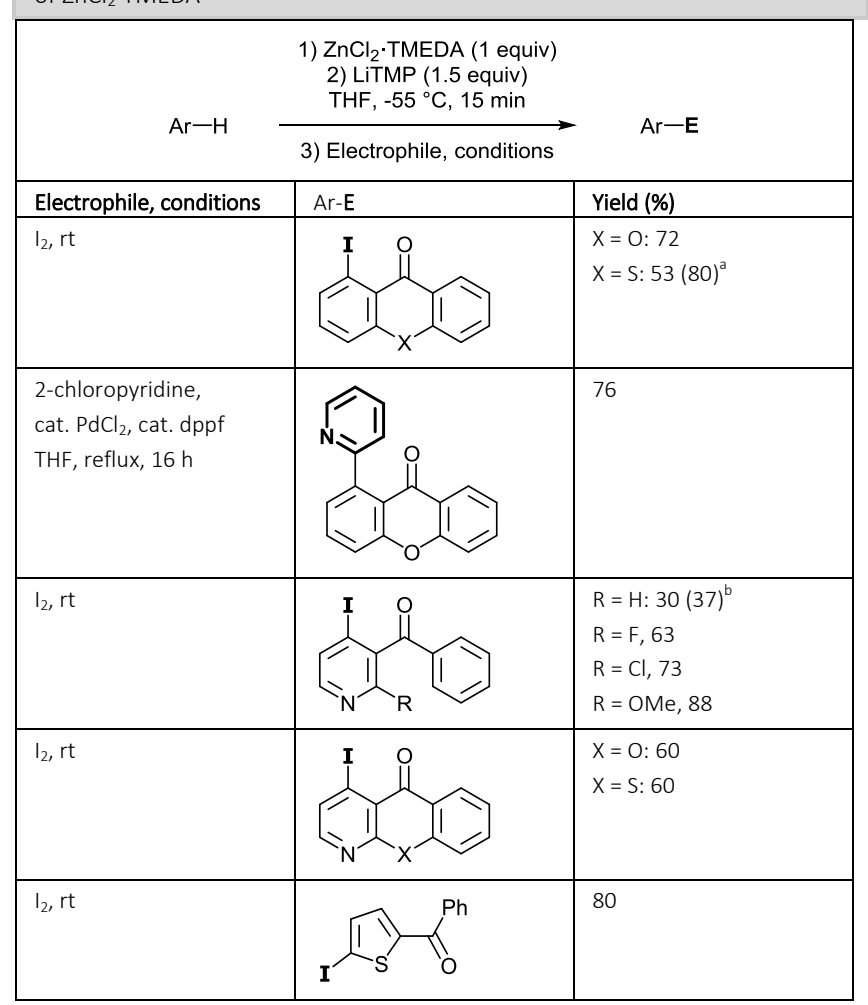

${ }^{\mathrm{a}}$ Reaction performed at $-30^{\circ} \mathrm{C}$. ${ }^{\mathrm{b}}$ Reaction performed at $-70^{\circ} \mathrm{C}$.

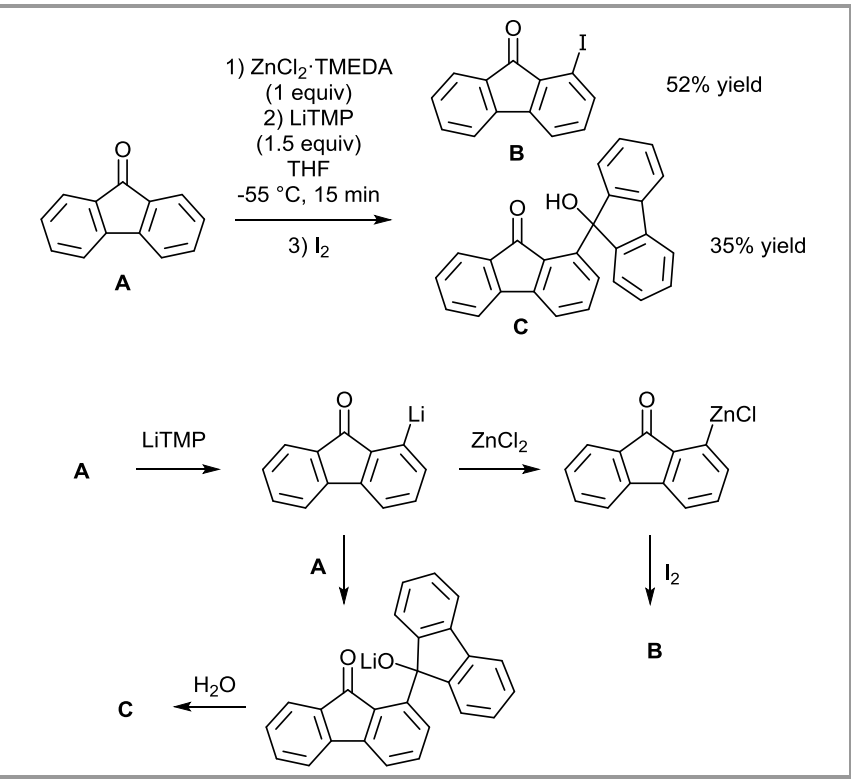

Scheme 18 Limitations of the $\mathrm{ZnCl}_{2} \cdot \mathrm{TMEDA}$ in situ trap

Dideprotonation (and sometimes more) has been observed in azole series by Chevallier and co-workers by increasing the amount of in situ generated 1:1 LiTMP-Zn(TMP)2.60 Interestingly, the lithium-zinc combination was employed to functionalize 2-arylated 1,2,3-triazoles. Indeed, whereas 2substituted 4-lithio-1,2,3-triazoles are unstable due to facile ring opening, here they can be trapped by the present zinc species and a second metalation can operate as exemplified in Scheme 19.61 


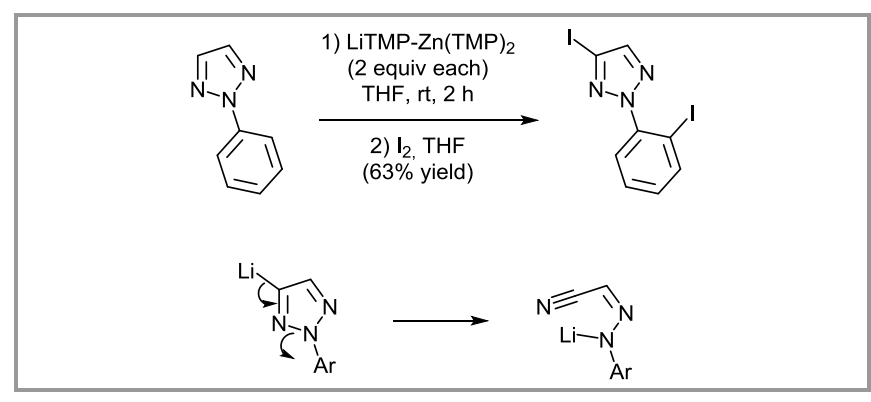

Scheme 19 Dideprotonation-iodolysis of 2-phenyl-1,2,3-triazole using 1:1 LiTMP-Zn(TMP) $)_{2}$ (generated from $\mathrm{ZnCl}_{2} \cdot$ TMEDA and LiTMP in a 1:3 ratio) and comparison with deprotolithiation

Benzotriazoles arylated on their terminal nitrogen were similarly difunctionalized by Mongin and co-workers. From 1phenyl- $1 H$-benzotriazole, the first deprotonation presumably occurs on the benzo ring, next to a coordinating triazole nitrogen that favors the approach of the base (position greatly favored using less base), and the second deprotonation on the phenyl ring, next to the second coordinating triazole nitrogen. ${ }^{55}$ Mulvey and co-workers studied the reaction without zinc trap, and deduced that deprotolithiation of the benzo ring is followed by benzyne formation with $\mathrm{N}_{2}$ extrusion, and addition of a second lithiobenzotriazole to the triple bond. ${ }^{62}$ The advantage of in situ 'trans-metal trapping' is once more evidenced (Scheme 20).

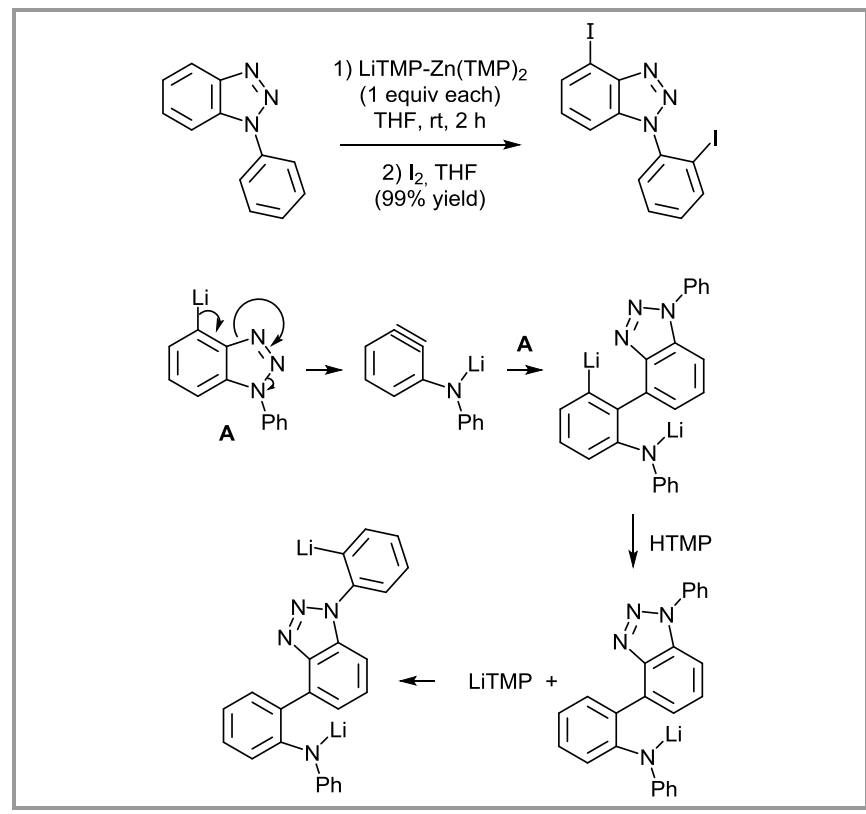

Scheme 20 Dideprotonation-iodolysis of 1-phenyl-1H-benzotriazole using 1:1 LiTMP-Zn(TMP) 2 (generated from $\mathrm{ZnCl}_{2} \cdot$ TMEDA and LiTMP in a 1:3 ratio) and comparison with deprotolithiation using LiTMP

In the pyridine series, various substrates are prone to dimetalation (e.g. 3-fluoro- and 2,6-difluoropyridine; Scheme 21) whereas others are not (e.g. 2-fluoropyridine, 2- and 4methoxypyridine) in the presence of an excess of base. This ability seems to be related to the acidity of the different pyridine substrates. ${ }^{63}$

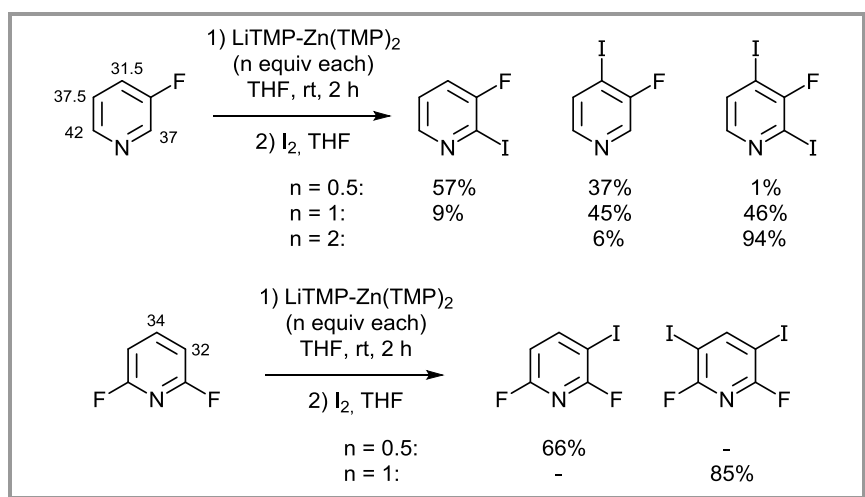

Scheme 21 Dideprotonation-iodolysis of 3-fluoro- and 2,6-difluoropyridine $\left(\mathrm{p} K_{\mathrm{a}}\right.$ values) using 1:1 LiTMP-Zn(TMP) 2 (generated from $\mathrm{ZnCl}_{2} \cdot \mathrm{TMEDA}$ and LiTMP in a $1: 3$ ratio)

\section{Aluminum- and gallium-based in situ traps}

Mulvey, Robertson and co-workers documented in 2012 the different pathways exhibited by the $\mathrm{LiAl}(\mathrm{TMP}) \mathrm{iBu}_{3}$ and $\mathrm{LiAl}(\mathrm{TMP})_{2} \mathrm{iBu}_{2}$ bases. Unlike the former, which allows 3halogenated anisoles to be easily deprotonated at their 2position, the latter makes the generated arylmetal species more reactive toward benzyne formation (due to the presence of the remaining TMP ligand). As regards the formation of this more reactive arylmetal, LiTMP-triggered deprotolithiation followed by in situ trapping with $\mathrm{iBu}_{2} \mathrm{Al}(\mathrm{TMP}$ ) was proposed (Scheme 22). ${ }^{64}$ Similarly, 3-fluoroanisole was converted to $3-(2,2,6,6-$ tetramethyl- $N$-piperidinyl)anisole in hexane or deuterated benzene. ${ }^{65}$

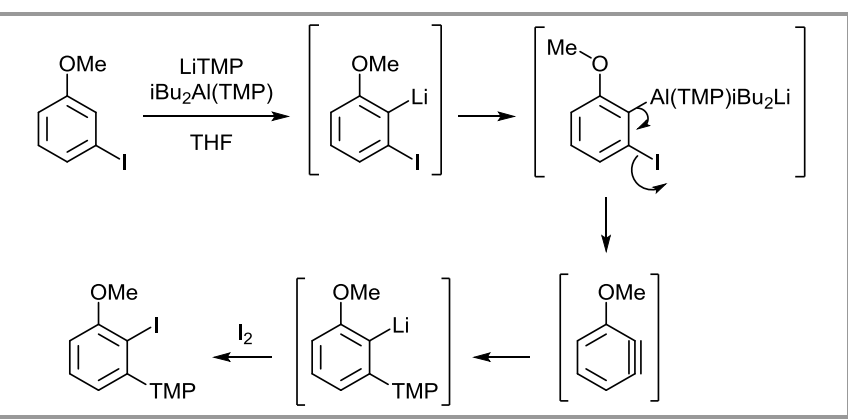

Scheme 22 Outcome of 3-iodoanisole deprotonation using LiTMP $\mathrm{iBu}_{2} \mathrm{Al}(\mathrm{TMP})$

An extended study published in 2014 on the structure of $\mathrm{LiAl}(\mathrm{TMP})_{2} \mathrm{iBu}_{2}$ led to the existence of two homometallic species, LiTMP.THF and $\mathrm{iBu}_{2} \mathrm{Al}(\mathrm{TMP}) \cdot \mathrm{THF}$, in THF solution. ${ }^{66}$ Thus, whereas LiTMP is responsible from deprotometalation, the reaction is driven by carbophilic and bulky iBu2Al(TMP); as a consequence, ortho-metalation of anisole works much more efficiently in the presence of the in situ trap (aluminated product produced in $99 \%$ yield) than without (5\% of lithiated anisole). ${ }^{67}$ The tandem LiTMP-iBu $2 \mathrm{Al}(\mathrm{TMP})$ can be employed in hexane at room temperature; when the reactions do not take place next to halogen, deprotonation occurs in high yields, as shown by subsequent iodolysis (Table 13). ${ }^{68}$ 


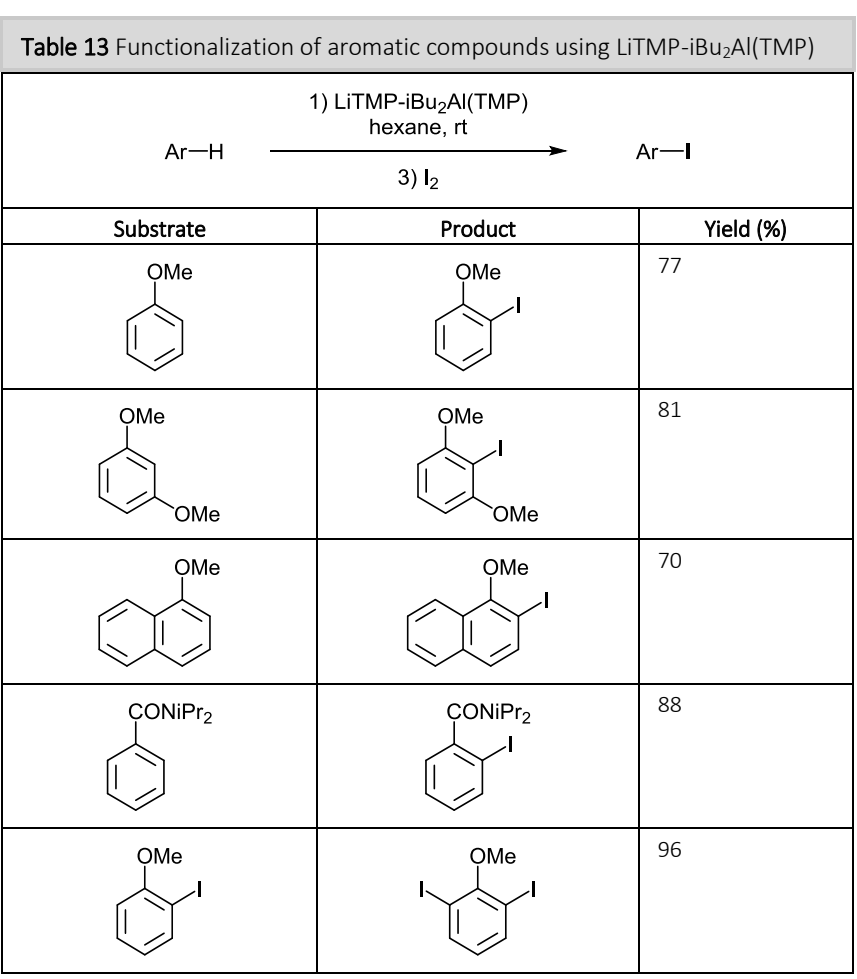

When ferrocene was treated by the 1:1 mixture of LiTMP and $\mathrm{iBu}_{2} \mathrm{Al}(\mathrm{TMP})$ in the presence of stoichiometric THF, either mono- or 1,1-dimetalation took place, depending on the amount of base. ${ }^{69}$

Hevia, Mulvey and co-workers evidenced in 2016 bulky and soluble $\mathrm{Ga}\left(\mathrm{CH}_{2} \mathrm{SiMe}_{3}\right)_{3}$ as new in situ trap for LiTMP-mediated deprotometalations. The tandem can be used in hexane at room temperature for pyrazine, pyridazine and pyrimidine monodeprotonation (base-trap-substrate ratio: 1:1:1). Pyrazine dideprotonation also takes place under stoichiometric control (base-trap-substrate ratio: 2:2:1) but not regioselectively, giving both the 2,5- and 2,6-gallated products in a 62:38 ratio. ${ }^{70}$

When compared with $\mathrm{iBu}_{2} \mathrm{Al}(\mathrm{TMP}), \mathrm{Ga}\left(\mathrm{CH}_{2} \mathrm{SiMe}_{3}\right)_{3}$ in situ trap gives more stable 2-metalated fluorobenzenes upon LiTMPinduced deprotometalation in hexane at low temperature. 65

\section{Other in situ traps}

In the frame of this Short Review, we focused on the most commonly encountered in situ traps. We will here mention a few examples that show other species can be used to intercept polar arylmetals as soon as they are formed.

Deprotonations using $\mathrm{Mg}(\mathrm{TMP})_{2} \cdot 2 \mathrm{LiCl}$ can be carried out in the presence of chlorotributylstannane or copper salt, as depicted in Scheme 23.52

More recently, $\mathrm{MgCl}_{2} \cdot 2 \mathrm{LiCl}$ and $\mathrm{CuCN} \cdot 2 \mathrm{LiCl}$ were more simply combined with LiTMP in order to diversify the further trapping steps (Scheme 24).56

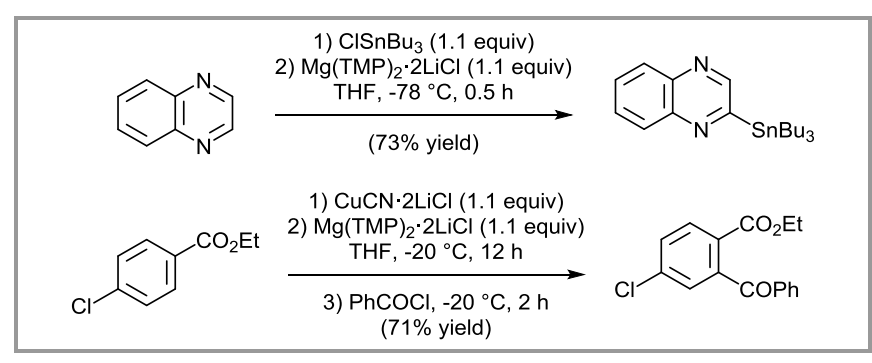

Scheme $23 \mathrm{Use}$ of $\mathrm{ClSnBu}$ and $\mathrm{CuCN} \cdot 2 \mathrm{LiCl}$ as in situ traps in combination with $\mathrm{Mg}(\mathrm{TMP})_{2} \cdot 2 \mathrm{LiCl}$

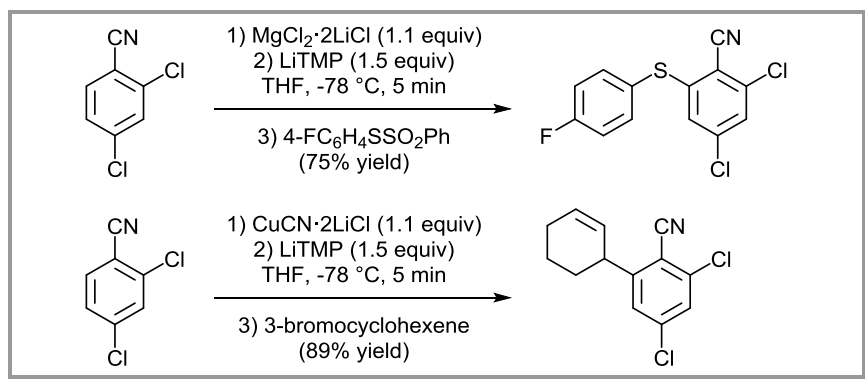

Scheme 24 Use of $\mathrm{MgCl}_{2} \cdot 2 \mathrm{LiCl}$ and $\mathrm{CuCN} \cdot 2 \mathrm{LiCl}$ as in situ traps in combination with LiTMP

\section{Continuous-flow in situ 'trans-metal trapping'}

In 2015, Becker and Knochel managed the flow deprotolithiation of various aromatic compounds including heterocycles in the presence of different metal salts, the obtained arylmetals being quenched in subsequent batch reactions (Table 14). The reaction scope under flow conditions is broader than that of the corresponding batch procedures. The reaction kinetics under continuous-flow mode differ significantly from those of the batch reactions, and contact times $<1 \mathrm{~min}$ are enough to ensure high yields. Importantly, cryogenic temperatures are no more required with the former since the reaction components are rapidly mixed, thus avoiding hot spots. Moreover, scale-up (from 1.7 to $12 \mathrm{mmol}$ in the present paper) can be performed without further optimization, just by using a longer time in the flow reactor. Interestingly, unusual kinetically controlled regioselectivities were noticed in several cases (e.g. deprotonation of ethyl 3-fluorobenzoate at C6 in spite of a more acidic hydrogen at C2). ${ }^{71}$

Table 14 Flow deprotometalation of aromatic compounds using LiTMP in the presence of metal salts $\left(\mathrm{A}=\mathrm{ZnCl}_{2} \cdot 2 \mathrm{LiCl} ; \mathrm{B}=\mathrm{MgCl}_{2} ; \mathrm{C}=\mathrm{CuCN} \cdot 2 \mathrm{LiCl} ; \mathbf{D}=\right.$ $\mathrm{LaCl}_{3} \cdot 2 \mathrm{LiCl}$ ) followed by batch electrophilic trapping

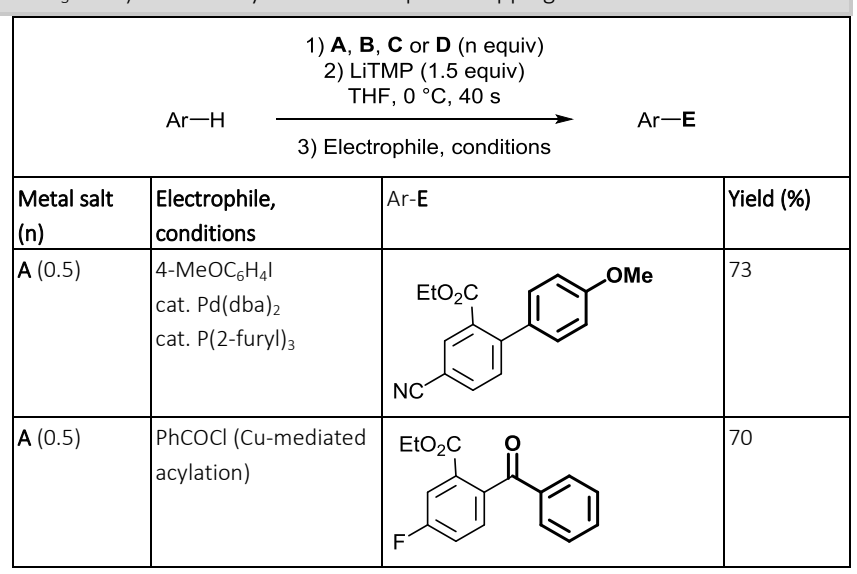




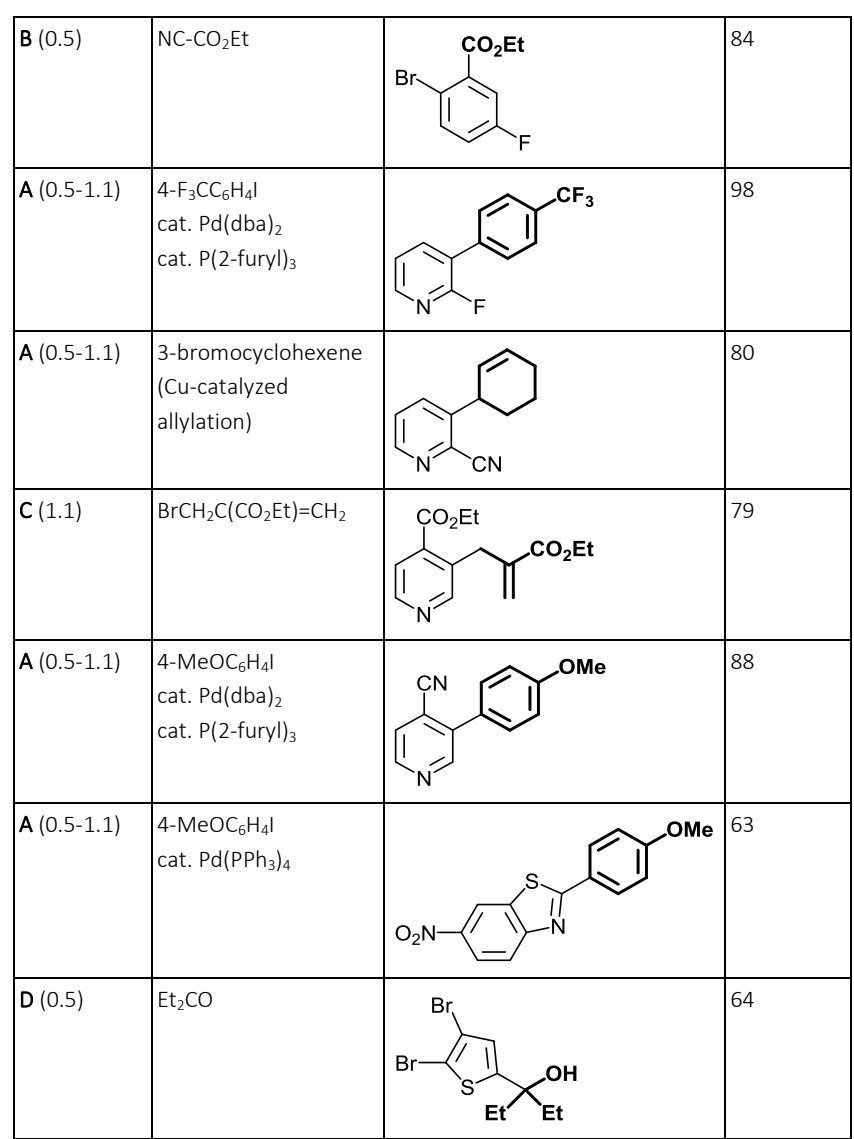

More recent studies performed on sensitive unsymmetrical azobenzenes, compounds of interest to access elaborated pharmaceuticals, and benzonitriles clearly evidence a large scope for in situ trapping metalations under continuous flow conditions (Table 15). ${ }^{72}$ Compared with the corresponding batch procedures, less equivalents of base of metal salt are required for the flow ones.

Dicyclohexylamine $\left(\mathrm{Cy}_{2} \mathrm{NH}\right)$ being far less expensive than 2,2,6,6-tetramethylpiperidine, the replacement of LiTMP by $\mathrm{LiNCy}_{2}$ was examined by Knochel and co-workers in 2015, and gave similar yields than LiTMP (Table 16). ${ }^{73}$

Table 15 Flow deprotometalation of unsymmetrical azobenzenes and benzonitriles using LiTMP in the presence of metal salts $\left(A=\mathrm{ZnCl}_{2} ; \mathbf{B}=\right.$ $\mathrm{MgCl}_{2} \cdot \mathrm{LiCl}$ ) followed by batch electrophilic trapping

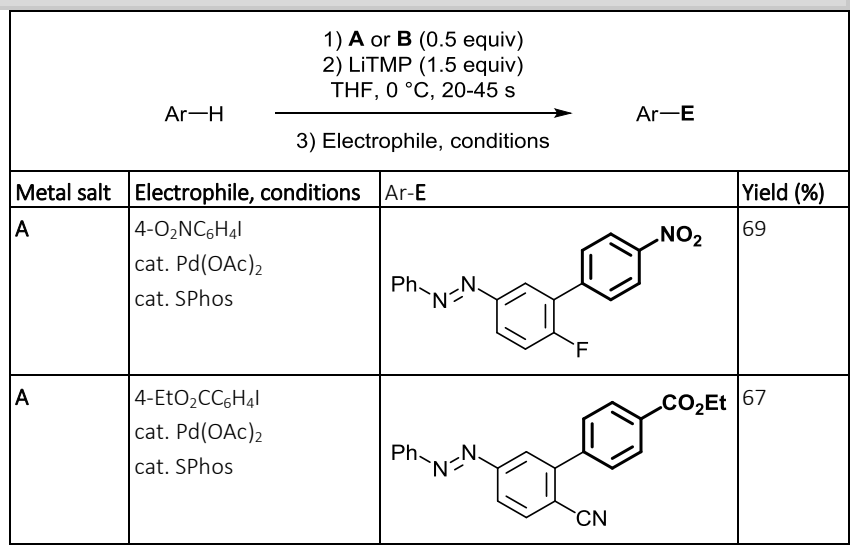

\begin{tabular}{|c|c|c|c|}
\hline$B$ & $\mathrm{ClSiMe}_{3}$ & $\mathrm{Ph}_{-}=\mathrm{N}$ & 92 \\
\hline A & $\begin{array}{l}\text { ClCOcPr, after } \\
\text { transmetalation with } \\
\text { CuCN } 2 \text { LiCl }\end{array}$ & & 78 \\
\hline A & $\begin{array}{l}\text { 4-EtO }{ }_{2} \mathrm{CC}_{6} \mathrm{H}_{4} \mathrm{l} \\
\text { cat. } \mathrm{Pd}(\mathrm{OAc})_{2} \\
\text { cat. SPhos }\end{array}$ & & 82 \\
\hline$A^{a}$ & $\mathrm{I}_{2}$ & I & 79 \\
\hline A & $\begin{array}{l}\mathrm{BrCH}{ }_{2} \mathrm{C}\left(\mathrm{CO}_{2} \mathrm{Et}\right)=\mathrm{CH}_{2} \\
\text { cat. } \mathrm{CuCN} \cdot 2 \mathrm{LiCl}\end{array}$ & & 58 \\
\hline
\end{tabular}

${ }^{\text {a }}$ Reaction performed at $-70^{\circ} \mathrm{C}$ instead of $0{ }^{\circ} \mathrm{C}$

Table 16 Flow deprotometalation of aromatic compounds using $\mathrm{LiNCy}_{2}$ in the presence of metal salts $\left(A=\mathrm{ZnCl}_{2} \cdot 2 \mathrm{LiCl} ; \mathrm{B}=\mathrm{MgCl}_{2} ; \mathrm{D}=\mathrm{LaCl}_{3} \cdot 2 \mathrm{LiCl}\right)$ followed by batch electrophilic trapping

\begin{tabular}{|c|c|c|c|}
\hline & \multirow{2}{*}{$\mathrm{Ar}-\mathrm{H}$} & \multirow{2}{*}{$\begin{array}{l}\text { 1) A, } \mathbf{B}, \mathbf{C} \text { or } \mathbf{D}(0.5 \text { equiv) } \\
\text { 2) LiTMP ( } 1.5 \text { equiv) } \\
\text { THF, } 0{ }^{\circ} \mathrm{C}, 40 \mathrm{~s} \\
\text { 3) Electrophile, conditions }\end{array}$} & \\
\hline & & & \\
\hline Metal salt & Electrophile, conditions & Ar-E & Yield (\%) \\
\hline B & $\mathrm{PhSO}_{2} \mathrm{SPh}$ & $\mathrm{F}$ & 75 \\
\hline A & $\begin{array}{l}\text { 4- } \mathrm{EtO}_{2} \mathrm{CC}_{6} \mathrm{H}_{4} \mathrm{l} \\
\text { cat. } \mathrm{Pd}(\mathrm{dba})_{2} \\
\text { cat. } \mathrm{P}(2 \text {-furyl })_{3}\end{array}$ & EtO & 72 \\
\hline A & $\begin{array}{l}\mathrm{RC}_{6} \mathrm{H}_{4} \mathrm{l} \\
\text { cat. } \mathrm{Pd}(\mathrm{dba})_{2} \\
\text { cat. } \mathrm{P}(2 \text {-furyl })_{3}\end{array}$ & & $\begin{array}{l}97 \text { (3-OMe) } \\
73(4-\mathrm{CN})\end{array}$ \\
\hline A & $\begin{array}{l}\text { 4- } \mathrm{EtO}_{2} \mathrm{CC}_{6} \mathrm{H}_{4} \mathrm{l} \\
\text { cat. } \mathrm{Pd}(\mathrm{dba})_{2} \\
\text { cat. } \mathrm{P}(2 \text {-furyl })_{3}\end{array}$ & & 67 \\
\hline$A$ & $\begin{array}{l}\text { 3- } \mathrm{MeOC}_{6} \mathrm{H}_{4} \mathrm{l} \\
\text { cat. } \mathrm{Pd}(\mathrm{dba})_{2} \\
\text { cat. } \mathrm{P}(2 \text {-furyl })_{3}\end{array}$ & & 77 \\
\hline D & $4-\mathrm{ClC}_{6} \mathrm{H}_{4} \mathrm{CHO}$ & & 62 \\
\hline A & $\begin{array}{l}\text { 3-bromocyclohexene } \\
\text { (Cu-catalyzed allylation) }\end{array}$ & & 76 \\
\hline
\end{tabular}




\section{Conclusion}

The development of in situ 'trans-metal trapping' allowed the limits of aromatic deprotometalation to be extended (tolerance toward functional group, soft conditions to deprotonate less activated substrates), and the method is now used in multistep syntheses, such as that of the natural product 2,6-dichloro-3phenethylphenol below (3 steps, 63\% overall yield; Scheme 25). ${ }^{53}$ In addition, in situ 'trans-metal trapping' allowed unexpected regioselectivities to be reached (e.g. far from fluorine) as well as aromatic polymetalations.

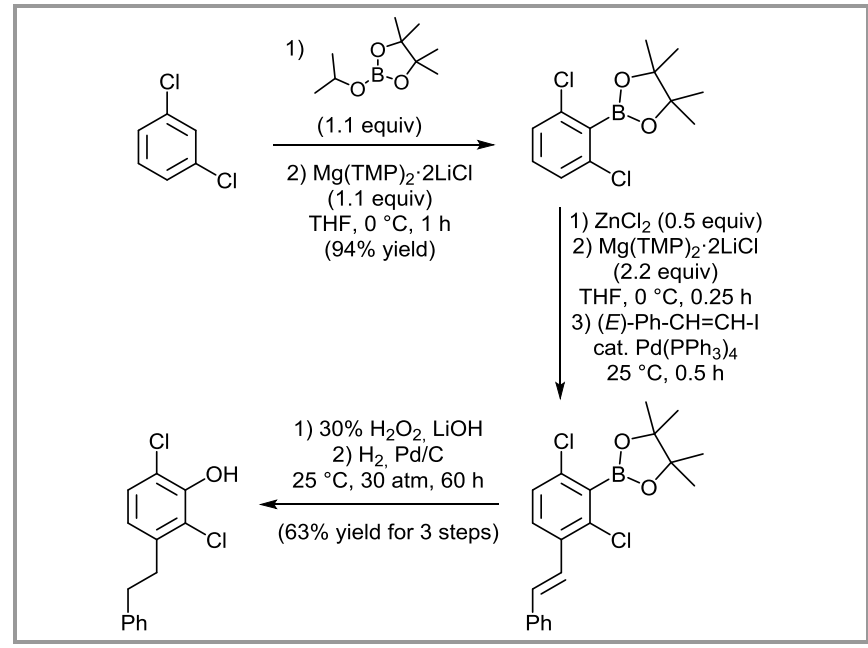

Scheme 25 Synthesis of the natural product 2,6-dichloro-3-phenethylphenol using in situ 'trans-metal trapping'

As shown in this short review, main group organometallics play a crucial role in organic synthesis. It is expected to continue to growth with the use of the methods presented in the synthesis of elaborated scaffolds. The increased compatibility gained by employing continuous flow reactions, as well as the low price and toxicity of the metal salts used here should contribute to this development.

\section{Funding Information}

Université de Rennes 1; Ministère de l'Enseignement supérieur et de la Recherche scientifique Algérien; Centre National de la Recherche Scientifique (PICS SYNAROM)

\section{Acknowledgment}

We thank the Université de Rennes 1 (W. E. and F. M.), the Ministère de l'Enseignement supérieur et de la Recherche scientifique Algérien (M. N. B.-N.) and the Centre National de la Recherche Scientifique (F. M.).

\section{References}

(1) (a) Gschwend, H. W.; Rodriguez, H. R. Org. React. (N.Y.) 1979, 26, 1. (b) Gant, T. G.; Meyers, A. I. Tetrahedron 1994, 50, 2297. (c) Schlosser, M. Organoalkali Chemistry, In Organometallics in Synthesis: A Manual, $2^{\text {nd }}$ ed.; Schlosser, M., Ed.; John Wiley \& Sons: Hoboken, 2002, Chap. 1, 1. (d) Hartung, C. G.; Snieckus, V. The Directed ortho Metalation of Aromatic Compounds, In Modern Arene Chemistry; Astruc, D., Ed.; 2002, 330. (e) Clayden, J. Directed Metalation of Aromatic Compounds, In Chemistry of Organolithium Compounds; Rappoport, Z.; Marek, I., Eds.; 2004, 1, 495. (f) Tilly, D.; Magolan, J.; Mortier, J. Chem. Eur. J. 2012, 18, 3804.

(2) See for example: Eaton, P. E.; Lee, C. H.; Xiong, Y. J. Am. Chem. Soc. 1989, 111, 8016.
(3) (a) Mulvey, R. E.; Mongin, F.; Uchiyama, M.; Kondo, Y. Angew. Chem. Int. Ed. 2007, 46, 3802. (b) Mulvey, R. E. Acc. Chem. Res. 2009, 42, 743. (c) Haag, B.; Mosrin, M.; Ila, H.; Malakhov, V.; Knochel, P. Angew. Chem. Int. Ed. 2011, 50, 9794. (d) Mongin, F.; Harrison-Marchand, A. Chem. Rev. 2013, 113, 7563. (e) Mulvey, R. E. Dalton Trans. 2013, 42, 6676. (f) Harford, P. J.; Peel, A. J.; Chevallier, F.; Takita, R.; Mongin, F.; Uchiyama, M.; Wheatley, A. E. H. Dalton Trans. 2014, 43, 14181.

(4) Lysén, M.; Hansen, H. M.; Begtrup, M.; Kristensen, J. L. J. Org. Chem. 2006, 71, 2518.

(5) Benischke, A. D.; Ellwart, M.; Becker, M. R.; Knochel, P. Synthesis 2016, 48, 1101.

(6) Note that lithium chloride, formed by using in situ traps such as chlorotrimethylsilane and zinc chloride, can also impact the reaction rate. See for example: (a) Lipshutz, B. H.; Wood, M. R.; Lindsley, C. W. Tetrahedron Lett. 1995, 36, 4385. (b) Gupta, L.; Hoepker, A. C.; Singh, K. J.; Collum, D. B. J. Org. Chem. 2009, 74, 2231. (c) Hevia, E.; Mulvey, R. E. Angew. Chem., Int. Ed. 2011, 50, 6448. (d) Liang, J.; Hoepker, A. C.; Algera, R. F.; Ma, Y.; Collum, D. B. J. Am. Chem. Soc. 2015, 137, 6292.

(7) In the frame of this Short Review, we discarded studies on the lithium-cadmium base "(TMP $)_{3} \mathrm{CdLi}$ " in spite of a probably similar behavior: (a) Mongin, F.; Uchiyama, M. Curr. Org. Chem. 2011, 15, 2340. (b) Armstrong, D. R.; Kennedy, A. R.; Mulvey, R. E.; Parkinson, J. A.; Robertson, S. D. Chem. Sci. 2012, 3, 2700.

(8) Marsais, F.; Laperdrix, B.; Güngör, T.; Mallet, M.; Queguiner, G. J. Chem. Res. (S) 1982, 278.

(9) Krizan, T. D.; Martin, J. C. J. Am. Chem. Soc. 1983, 105, 6155.

(10) Upton, C. J.; Beak, P. J. Org. Chem. 1975, 40, 1094.

(11) (a) Luliński, S.; Serwatowski, J. J. Org. Chem. 2003, 68, 5384. (b) Luliński, S.; Serwatowski, J. J. Org. Chem. 2003, 68, 9384.

(12) Decouzon, M.; Ertl, P.; Exner, O.; Gal, J.-F.; Maria, P.-C. J. Am. Chem. Soc. 1993, 115, 12071.

(13) Heiss, C.; Marzi, E.; Schlosser, M. Eur. J. Org. Chem. 2003, 4625.

(14) Gilman, H.; Gorsich, R. D. J. Am. Chem. Soc. 1956, 78, 2217.

(15) Erb, W.; Mongin, F. Tetrahedron 2016, 72, 4973.

(16) Widhalm, M.; Aichinger, C.; Mereiter, K. Tetrahedron Lett. 2009, $50,2425$.

(17) Dąbrowski, M.; Kubicka, J.; Luliński, S.; Serwatowski, J. Tetrahedron Lett. 2005, 46, 4175

(18) (a) Luliński, S.; Serwatowski, J.; Zaczek, A. Eur. J. Org. Chem. 2006 5167. (b) Mongin, F. Chimia 2016, 70, 48.

(19) Mesgar, M.; Daugulis, O. Org. Lett. 2016, 18, 3910.

(20) (a) Nguyen, T.-H.; Chau, N. T. T.; Castanet, A.-S.; Nguyen, K. P. P.; Mortier, J. Org. Lett. 2005, 7, 2445. See also: (b) Chau, N. T. T.; Nguyen, T. H.; Castanet, A.-S.; Nguyen, K. P. P.; Mortier, J. Tetrahedron 2008, 64, 10552.

(21) Michaux, J.; Bessières, B.; Einhorn, J. Tetrahedron Lett. 2012, 53 , 48.

(22) Black, W. C.; Guay, B.; Scheuermeyer, F. J. Org. Chem. 1997, 62, 758.

(23) (a) Gribble, G. W.; Saulnier, M. G. Tetrahedron Lett. 1980, 21, 4137. (b) Gribble, G. W.; Saulnier, M. G. Heterocycles 1993, 35, 151.

(24) Effenberger, F.; Daub, W. Chem. Ber. 1991, 124, 2119.

(25) Imahori, T.; Uchiyama, M.; Sakamoto, T.; Kondo, Y. Chem. Commun. 2001, 2450.

(26) Tilly, D.; Fu, J.-m.; Zhao, B.-p.; Alessi, M.; Castanet, A.-S.; Snieckus, V.; Mortier, J. Org. Lett. 2010, 12, 68.

(27) (a) Price, D. A.; Simpkins, N. S.; MacLeod, A. M.; Watt, A. P. J. Org. Chem. 1994, 59, 1961. (b) Ewin, R. A.; MacLeod, A. M.; Price, D. A.; Simpkins, N. S.; Watt, A. P. J. Chem. Soc., Perkin Trans. 1 1997, 401.

(28) See also: Schmalz, H.-G.; Schellhaas, K. Tetrahedron Lett. 1995, 36, 5515.

(29) Price, D.; Simpkins, N. S. Tetrahedron Lett. 1995, 36, 6135.

(30) Mongin, F.; Curty, C.; Marzi, E.; Leroux, F. R.; Schlosser, M. ARKIVOC 2015, 48

(31) Caron, S.; Hawkins, J. M. J. Org. Chem. 1998, 63, 2054. 
(32) Fraser, R. R.; Mansour, T. S.; Savard, S. J. Org. Chem. 1985, 50, 3232.

(33) Kristensen, J.; Lysen, M.; Vedsø, P.; Begtrup, M. Org. Lett. 2001, 3 1435.

(34) Iwao, M. J. Org. Chem. 1990, 55, 3622.

(35) Hansen, H. M.; Lysén, M.; Begtrup, M.; Kristensen, J. L. Tetrahedron 2005, 61, 9955.

(36) Alessi, M.; Larkin, A. L.; Ogilvie, K. A.; Green, L. A.; Lai, S.; Lopez, S.; Snieckus, V.J. Org. Chem. 2007, 72, 1588.

(37) Cederbalk, A.; Lysén, M.; Kehler, J.; Kristensen, J. L. Tetrahedron 2017, 73, 1576.

(38) (a) Jaric, M.; Haag, B. A.; Unsinn, A.; Karaghiosoff, K.; Knochel, P. Angew. Chem. Int. Ed. 2010, 49, 5451. (b) Jaric, M.; Haag, B. A.; Manolikakes, S. M.; Knochel, P. Org. Lett. 2011, 13, 2306. (c) Groll, K.; Manolikakes, S. M.; Mollat du Jourdin, X.; Jaric, M.; Bredihhin, A.; Karaghiosoff, K.; Carell, T.; Knochel, P. Angew. Chem., Int. Ed. 2013, 52, 6776.

(39) Seggio, A.; Lannou, M.-I.; Chevallier, F.; Nobuto, D.; Uchiyama, M.; Golhen, S.; Roisnel, T.; Mongin, F. Chem. Eur. J. 2007, 13, 9982.

(40) (a) L'Helgoual'ch, J. M.; Seggio, A.; Chevallier, F.; Yonehara, M.; Jeanneau, E.; Uchiyama, M.; Mongin, F. J. Org. Chem. 2008, 73, 177. (b) Snégaroff, K.; Komagawa, S.; Chevallier, F.; Gros, P. C.; Golhen, S.; Roisnel, T.; Uchiyama, M.; Mongin, F. Chem. Eur. J. 2010, 16, 8191. (c) García-Álvarez, P.; Mulvey, R. E.; Parkinson, J. A. Angew. Chem. Int. Ed. 2011, 50, 9668.

(41) Plé, N.; Turck, A.; Couture, K.; Quéguiner, G. J. Org. Chem. 1995, 60, 3781.

(42) Seggio, A.; Chevallier, F.; Vaultier, M.; Mongin, F. J. Org. Chem. 2007, 72, 6602.

(43) Snégaroff, K.; Nguyen, T. T.; Marquise, N.; Halauko, Y. S.; Harford, P. J.; Roisnel, T.; Matulis, V. E.; Ivashkevich, O. A.; Chevallier, F.; Wheatley, A. E. H.; Gros, P. C.; Mongin, F. Chem. Eur. J. 2011, 17, 13284.

(44) Ameur Messaoud, M. Y.; Bentabed-Ababsa, G.; Hedidi, M.; Derdour, A.; Chevallier, F.; Halauko, Y. S.; Ivashkevich, O. A.; Matulis, V. E.; Picot, L.; Thiéry, V.; Roisnel, T.; Dorcet, V.; Mongin, F. Beilstein J. Org. Chem. 2015, 11, 1475.

(45) (a) Kadiyala, R. R.; Tilly, D.; Nagaradja, E.; Roisnel, T.; Matulis, V. E.; Ivashkevich, O. A.; Halauko, Y. S.; Chevallier, F.; Gros, P. C.; Mongin, F. Chem. Eur. J. 2013, 19, 7944. (b) Marquise, N.; Bretel, G.; Lassagne, F.; Chevallier, F.; Roisnel, T.; Dorcet, V.; Halauko, Y. S.; Ivashkevich, O. A.; Matulis, V. E.; Gros, P. C.; Mongin, F. RSC Adv. 2014, 4, 19602. (c) Marquise, N.; Nguyen, T. T.; Chevallier, F.; Picot, L.; Thiery, V.; Lozach, O.; Bach, S.; Ruchaud, S.; Mongin, F. Synlett 2015, 26, 2811.

(46) (a) Dayaker, G.; Sreeshailam, A.; Chevallier, F.; Roisnel, T.; Radha Krishna, P.; Mongin, F. Chem. Commun. 2010, 46, 2862. (b) Tazi, M.; Erb, W.; Halauko, Y. S.; Ivashkevich, O. A.; Matulis, V. E.; Roisnel, T.; Dorcet, V.; Mongin, F. Organometallics 2017, 36, 4770.

(47) Dayaker, G.; Tilly, D.; Chevallier, F.; Hilmersson, G.; Gros, P. C.; Mongin, F. Eur. J. Org. Chem. 2012, 6051.

(48) (a) Sreeshailam, A.; Dayaker, G.; Ramana, D. V.; Chevallier, F.; Roisnel, T.; Komagawa, S.; Takita, R.; Uchiyama, M.; Radha Krishna, P.; Mongin, F. RSC Adv. 2012, 2, 7030. (b) Dayaker, G.; Sreeshailam, A.; Ramana, D. V.; Chevallier, F.; Roisnel, T.; Komagawa, S.; Takita, R.; Uchiyama, M.; Krishna, P. R.; Mongin, F. Tetrahedron 2014, 70, 2102.

(49) (a) Eaton, P. E.; Castaldi, G. J. Am. Chem. Soc. 1985, 107, 724. (b) Eaton, P. E.; Higuchi, H.; Millikan, R. Tetrahedron Lett. 1987, 28 , 1055.
(50) Eaton, P. E.; Daniels, R. G.; Casucci, D.; Cunkle, G. T.; Engel, P. J. Org. Chem. 1987, 52, 2100.

(51) Eaton, P. E.; Cunkle, G. T.; Marchioro, G.; Martin, R. M. J. Am. Chem. Soc. 1987, 109, 948.

(52) Dong, Z.; Clososki, G. C.; Wunderlich, S. H.; Unsinn, A.; Li, J.; Knochel, P. Chem. Eur. J. 2009, 15, 457.

(53) Unsinn, A.; Rohbogner, C. J.; Knochel, P. Adv. Synth. Catal. 2013 , 355, 1553.

(54) Unsinn, A.; Wunderlich, S. H.; Knochel, P. Adv. Synth. Catal. 2013 $355,989$.

(55) Nagaradja, E.; Chevallier, F.; Roisnel, T.; Dorcet, V.; Halauko, Y. S.; Ivashkevich, O. A.; Matulis, V. E.; Mongin, F. Org. Biomol. Chem. 2014, 1475.

(56) Frischmuth, A.; Fernández, M.; Barl, N. M.; Achrainer, F.; Zipse, H.; Berionni, G.; Mayr, H.; Karaghiosoff, K.; Knochel, P. Angew. Chem. Int. Ed. 2014, 53, 7928.

(57) (a) Hedidi, M.; Erb, W.; Lassagne, F.; Halauko, Y. S.; Ivashkevich, O. A.; Matulis, V. E.; Roisnel, T.; Bentabed-Ababsa, G.; Mongin, F. RSC Adv. 2016, 6, 63185. (b) Hedidi, M.; Maillard, J.; Erb, W.; Lassagne, F.; Halauko, Y. S.; Ivashkevich, O. A.; Matulis, V. E.; Roisnel, T.; Dorcet, V.; Hamze, M.; Fajloun, Z.; Baratte, B.; Ruchaud, S.; Bach, S.; Bentabed-Ababsa, G.; Mongin, F. Eur. J. Org. Chem. 2017, 5903.

(58) Amara, R.; Bentabed-Ababsa, G.; Hedidi, M.; Khoury, J.; Awad, H.; Nassar, E.; Roisnel, T.; Dorcet, V.; Chevallier, F.; Fajloun, Z.; Mongin, F. Synthesis 2017, 49, 4500.

(59) Eaton, P. E.; Martin, R. M. J. Org. Chem. 1988, 53, 2728.

(60) (a) Chevallier, F.; Halauko, Y. S.; Pecceu, C.; Nassar, I. F.; Dam, T. U.; Roisnel, T.; Matulis, V. E.; Ivashkevich, O. A.; Mongin, F. Org. Biomol. Chem. 2011, 9, 4671. (b) Nagaradja, E.; Bentabed-Ababsa, G.; Scalabrini, M.; Chevallier, F.; Philippot, S.; Fontanay, S.; Duval, R. E.; Halauko, Y. S.; Ivashkevich, O. A.; Matulis, V. E.; Roisnel, T.; Mongin, F. Bioorg. Med. Chem. 2015, 23, 6355.

(61) Chevallier, F.; Blin, T.; Nagaradja, E.; Lassagne, F.; Roisnel, T.; Halauko, Y. S.; Matulis, V. E.; Ivashkevich, O. A.; Mongin, F. Org. Biomol. Chem. 2012, 10, 4878.

(62) Fuentes, M. A.; Kennedy, A. R.; Mulvey, R. E.; Parkinson, J. A.; Rantanen, T.; Robertson, S. D.; Snieckus, V. Chem. Eur. J. 2015, 21, 14812.

(63) Hedidi, M.; Bentabed-Ababsa, G.; Derdour, A.; Halauko, Y. S.; Ivashkevich, O. A.; Matulis, V. E.; Chevallier, F.; Roisnel, T.; Dorcet, V.; Mongin, F. Tetrahedron 2016, 72, 2196.

(64) Crosbie, E.; Kennedy, A. R.; Mulvey, R. E.; Robertson, S. D. Dalton Trans. 2012, 41, 1832.

(65) McLellan, R.; Uzelac, M.; Kennedy, A. R.; Hevia, E.; Mulvey, R. E. Angew. Chem., Int. Ed. 2017, 56, 9566.

(66) Armstrong, D. R.; Crosbie, E.; Hevia, E.; Mulvey, R. E.; Ramsay, D. L.; Robertson, S. D. Chem. Sci. 2014, 5, 3031.

(67) Uzelac, M.; Kennedy, A. R.; Hevia, E. Inorg. Chem. 2017, 56, 8615.

(68) Mulvey, R. E.; Armstrong, D. R.; Conway, B.; Crosbie, E.; Kennedy, A. R.; Robertson, S. D. Inorg. Chem. 2011, 50, 12241.

(69) Clegg, W.; Crosbie, E.; Dale-Black, S. H.; Hevia, E.; Honeyman, G. W.; Kennedy, A. R.; Mulvey, R. E.; Ramsay, D. L.; Robertson, S. D. Organometallics 2015, 34, 2580.

(70) Uzelac, M.; Kennedy, A. R.; Hevia, E.; Mulvey, R. E. Angew. Chem., Int. Ed. 2016, 55, 13147.

(71) Becker, M. R.; Knochel, P. Angew. Chem. Int. Ed. 2015, 54, 12501.

(72) (a) Ketels, M.; Konrad, D. B.; Karaghiosoff, K.; Trauner, D.; Knochel, P. Org. Lett. 2017, 19, 1666. (b) Ketels, M.; Ziegler, D. S.; Knochel, P. Synlett 2017, 28, 2817.

(73) Becker, M. R.; Ganiek, M. A.; Knochel, P. Chem. Sci. 2015, 6, 6649. 


\section{Biosketches}

William Erb obtained his Ph.D. in organic chemistry in 2010 under the supervision of Prof. Jieping Zhu
on total synthesis of natural products and palladium-catalyzed reactions. During the next four years of
postdoctoral studies he worked in various laboratories on different research projects from
organocatalysis to supramolecular chemistry with an emphasis on new methodologies development
(University of Bristol, Prof. Varinder Aggarwal, UK - ESPCI, Prof. Janine Cossy, Paris - LCMT, Prof.
Jacques Rouden, Caen - COBRA, Prof. Géraldine Gouhier, Rouen). He was appointed assistant professor
at the University of Rennes (France) in 2015 where he is mainly working on the development of original
ferrocene functionalizations.

\begin{tabular}{|l|l|} 
Florence Mongin obtained her Ph.D. in Chemistry in 1994 from the University of Rouen (France) under \\
the supervision of Prof. Guy Queguiner. After a two-year stay at the Institute of Organic Chemistry of \\
Lausanne (Switzerland) as a postdoctoral fellow with Prof. Manfred Schlosser, she returned to the \\
University of Rouen as an Assistant Professor in 1997 (HDR in 2003). She took up her present position \\
in 2005 as Professor at the University of Rennes (France) and was appointed Junior Member of the \\
Institut Universitaire de France in 2009. Her present scientific interests include the functionalization of \\
aromatic compounds including heterocycles with recourse to bimetallic bases or combinations.
\end{tabular}

